Northwestern University School of Law Northwestern University School of Law Scholarly Commons

Faculty Working Papers

2010

\title{
The Constitutionality of International Courts: The Forgotten Precedent of Slave Trade Tribunals
}

Eugene Kontorovich

Northwestern University School of Law, e-kontorovich@law.northwestern.edu

\section{Repository Citation}

Kontorovich, Eugene, "The Constitutionality of International Courts: The Forgotten Precedent of Slave Trade Tribunals" (2010).

Faculty Working Papers. Paper 178.

http://scholarlycommons.law.northwestern.edu/facultyworkingpapers/178

This Working Paper is brought to you for free and open access by Northwestern University School of Law Scholarly Commons. It has been accepted for inclusion in Faculty Working Papers by an authorized administrator of Northwestern University School of Law Scholarly Commons. 


\section{ARTICLE}

THE CONSTITUTIONALITY OF INTERNATIONAL COURTS:

THE FORGOTTEN PRECEDENT OF

SLAVE-TRADE TRIBUNALS

\section{EUGENE KONTOROVICH ${ }^{\dagger}$}

Nor is the aggravation of the crime for the trial of which a tribunal may be instituted[] a cogent motive for assenting to the principle of subjecting American citizens ... to the decision of foreign courts; for although Great Britain ... may be willing to abandon those of her subjects who defy the laws and tarnish the character of their country[] by [committing human rights abuses], to the dispensation of justice even by foreign hands, the United States are bound to remember that the power which enables a court to try the guilty, authorizes them also to pronounce upon the fate of the innocent; and that the very question of guilt or innocence is that which the protecting care of their Constitution has reserved for the citizens of this Union, to the exclusive decision of their own countrymen.

John Quincy Adams ${ }^{1}$

The United States' participation in international courts and, in particular, its potential accession to the International Criminal Court (ICC), a court that would have jurisdiction over U.S. nationals and U.S. territory, raise serious constitutional questions. These questions were thoroughly analyzed in the course of the debate about the constitutionality of international courts proposed

${ }^{\dagger}$ Associate Professor, Northwestern University School of Law. The author thanks Robert Howse, Jide Nzelibe, John McGinnis, Jeremy Rabkin, Martin Redish, Jim Pfander, and John Parry, participants in the Georgetown University Law School's Foreign Relations Law Colloquium, for helpful comments and discussions, as well as Steven Art and the Northwestern University School of Law Faculty Research Program for assistance and support.

${ }^{1} 42$ AnNAls OF CONG. app. at 3012 (1823) (letter from John Quincy Adams to Stratford Canning). 
by Britain in the early nineteenth century, an episode that has never before been examined for its relevance to current legal and policy debates. This Article presents that historical debate and draws lessons for the present.

The permissibility of the United States joining international tribunals spans several major constitutional issues: the delegation of federal powers to supernational institutions; the limits, if any, on what the treaty power can do; and the vesting of judicial power in non-Article III courts. While these are all famously confused and contentious areas of law, the preponderance of scholarly opinion concludes that the Constitution does not bar the United States from joining international courts, including the ICC.

The jurisprudence and literature on these questions, however, have neglected an important precedent. In the wake of the Napoleonic Wars, a network of international tribunals to punish slave trading was created. Many European nations joined these "mixed courts." The United States, however, saw the courts as unconstitutional. It refused to join the mixed-court system for fortyfive years, a period that spanned eleven presidencies. Constitutional objections were formulated by some of the leading statesmen of the early Republic and even by some members of the founding generation. They were unanimous in their view that the Constitution forbids joining an international criminal court with jurisdiction over American nationals.

They raised several constitutional objections of both structural and individual-rights varieties. The United States complained, in a long series of diplomatic missives, that such a court's decisions would not be reviewable by the Supreme Court and that, even more importantly, the court would subject U.S. nationals to criminal trials without a jury and other Bill of Rights protections. These objections were unanimously held in James Monroe's distinguished Cabinet, shared by Congress, and undisputed by anyone for decades.

This Article examines the constitutional objections stated at the time of the slave-trade courts and shows that some, but not all, international criminal courts are likely to be unconstitutional, while noncriminal international tribunals are far less problematic. The foregoing suggests that it would be unconstitutional to join an international criminal court with jurisdiction over certain offenses, some of which are within the ICC's charter. The evidence presented here can guide the tailoring of such courts' jurisdiction to avoid constitutional conflicts.

Aside from the precedential significance, the nineteenth-century discussion of why joining such a court would be impermissible speaks directly to today's constitutional jurisprudence in modern terms. It provides surprisingly relevant guidance on questions such as the permissibility of non-Article III courts, constitutional restraints on the treaty power, and the binding effect of judgments of international courts. Additionally, nearly every argument made today about 
American exceptionalism in international law and concerning the conflict between domestic and international law was rehearsed nearly two hundred years ago.

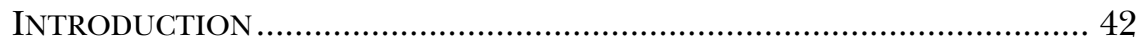

I. CURRENT CONSTITUTIONAL Debates............................................. 48

A. Non-Article III Courts.......................................................... 49

1. The Nineteenth Century: Territorial, Military, and Consular Courts ................................. 49

2. The Twentieth Century: Administrative Courts and Public Rights .................................................... 52

3. The Availability of Article III Review........................ 54

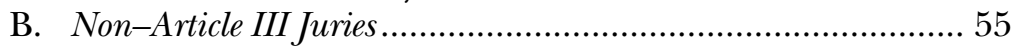

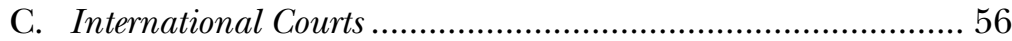

II. THE REJECTION OF MiXed COURTS............................................... 58

A. The Campaign Against the Slave Trade .................................... 60

B. Rejecting the Mixed-Courts Proposal......................................... 62

C. Not Taking "No" for an Answer .............................................. 64

1. A Second Cabinet Meeting........................................ 65

2. Trading Canada for Commissions? ........................... 66

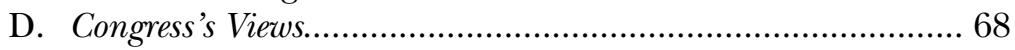

E. Commissions Overboard …....................................................... 70

III. UNDERSTANDING THE CONSTITUTIONAL OBJECTIONS ...................... 74

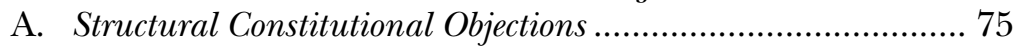

1. Wirt's Nondelegation Arguments ............................ 75

2. Adams's Appellate Objections.................................. 77

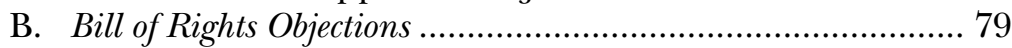

C. The Importance of Criminal Jurisdiction.................................. 82

D. The Precedential Value of the Rejection ..................................... 86

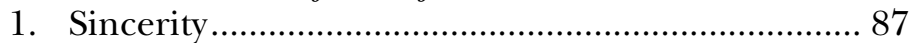

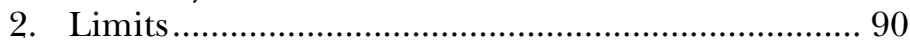

3. Universal Jurisdiction ............................................. 91

4. Offenses by Service Members ................................... 92

5. Foreign Territory ……………................................... 93

IV. CIVIL WAR AND CIVIL SUITS......................................................... 94

A. Quick Negotiations................................................................. 95

B. The Constitutional Argument ............................................... 96

C. A Court with No Cases .......................................................... 98

D. The Precedential Value of the Acceptance ……........................... 99

V. IMPLICATIONS FOR MODERN COURTS AND DEBATES .......................102

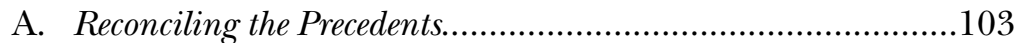

1. The Stronger Precedent ..........................................103

2. An Area of Agreement ..............................................104 


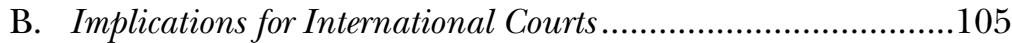

C. The Rome Treaty's Overbreadth..............................................106

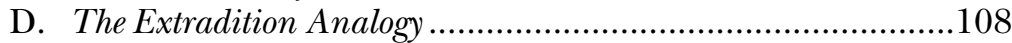

E. Non-Article III Courts and the Treaty Power ...........................113

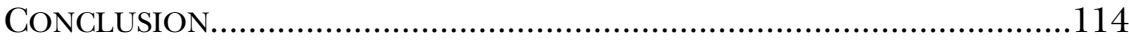

\section{INTRODUCTION}

International courts ${ }^{2}$ play a small but growing role in resolving interstate disputes as well as in directly applying criminal law to individuals. The United States' participation in such tribunals raises an array of serious constitutional questions-questions that are particularly urgent in light of the United States' potential accession to the International Criminal Court (ICC), for this court would have jurisdiction over U.S. nationals and U.S. territory. ${ }^{3}$ This Article presents perhaps the best source of understanding these questions: the discussion of the constitutionality of joining international courts to try slave traders in the early nineteenth century. This obscure episode has never before been examined for its relevance to current constitutional debates.

The permissibility of the United States joining international tribunals spans two major constitutional issues: the vesting of judicial power in non-Article III courts and the delegation of federal powers to supernational institutions through the treaty power. ${ }^{4}$ Both areas of law are known for their zigzagging lines of cases and contentious academic debate. Nonetheless, the preponderance of scholarly opinion

${ }^{2}$ This Article uses the terms "courts" and "tribunals" interchangeably unless otherwise specified.

${ }^{3}$ See Press Release, Am. Soc'y of Int'l Law, American Society for International Law Task Force Issues Recommendations on U.S. Policy Toward the International Criminal Court (Feb. 2, 2009), available at http://www.asil.org/pdfs/pressreleases/pr090202.pdf (recommending that the United States consider joining the ICC).

${ }^{4}$ See, e.g., Julian G. Ku, The Delegation of Federal Power to International Organizations: New Problems with Old Solutions, 85 MINN. L. Rev. 71, 93-99, 110-12 (2000) (exploring how "delegations to international organizations can ... create conflicts with the Constitution's basic structural requirements"); John O. McGinnis, Medellín and the Future of International Delegation, 118 YALE L.J. 1712, 1742-47 (2009) (discussing how the Treaty Clause "answers the [constitutional] complaints under ... Article III" by creating the "capacity to enter into international federations and create international tribunals" that have "binding power under [U.S.] law"). 
concludes that the Constitution permits U.S. participation in the ICC and similar tribunals.

The literature on these questions, however, has neglected an important precedent. In the wake of the Napoleonic Wars, Britain created a network of international tribunals to punish slave trading. Many European nations joined these "mixed courts." The United States refused to participate, arguing that the Constitution forbade joining an international criminal court with jurisdiction over American nationals. The constitutional objections were formulated by some of the leading statesmen of the early Republic, including some members of the founding generation. As with the ICC, an initial rebuff by the United States did not end efforts to secure U.S. membership. Still, the United States stayed aloof from the mixed-court system for forty-five years-a period spanning eleven presidencies with varied politics and attitudes toward Britain, international engagement, and the slave trade.

This history raises serious questions about the constitutionality of joining the ICC or other international tribunals that would have jurisdiction over U.S. nationals. The evidence presented in this Article suggests that giving an international criminal court jurisdiction over certain offenses within the ICC's charter would generally be unconstitutional. This does not mean, however, that U.S. participation in international criminal courts would always be unconstitutional. While the ICC runs afoul of constitutional limitations, the story of the slave-

${ }^{5}$ See, e.g., AM. SOC'Y OF INT'L LAW, U.S. POLICY TOWARD THE INTERNATIONAL Criminal COURT: Furthering Positive Engagement 41 (2009), available at http:// www.asil.org/files/ASIL-08-DiscPaper2.pdf (concluding that "these [constitutional] concerns do not present any insurmountable obstacles to joining the Court"); LOUIS HENkin, Foreign AFFAIRS AND the United STATES CONSTITUTION 270 (2d ed. 1996) (stating that U.S. participation in the ICC "would not be constitutionally troublesome”); David Scheffer \& Ashley Cox, The Constitutionality of the Rome Statute of the International Criminal Court, 98 J. CRIM. L. \& CRIMINOLOGY 983, 1065-68 (2008) (concluding that ratification of the Rome Statute would be constitutional); Ruth Wedgwood, The Constitution and the ICC (discussing the United States' past participation in international tribunals and concluding that "there is no forbidding constitutional obstacle to U.S. participation in [the ICC]"), in THE UNITED STATES AND THE INTERNATIONAL CRIMINAl COURT: NATIONAl SECURity AND InTERnATIONAL LAW 119, 121-22 (Sarah B. Sewall \& Carl Kaysen eds., 2000); see also Monroe Leigh, Editorial Comment, The United States and the Statute of Rome, 95 AM. J. INT'L L. 124, 131 (2001) (dismissing as "totally misplaced" the "criticism that under the ICC United States service personnel will be denied due process protections"). But see Lee A. Casey, The Case Against the International Criminal Court, 25 FORDHAM INT'L L.J. 840, 841-42 (2002) (arguing that ratification of the Rome Statute would not only be inconsistent with American democracy but also unconstitutional). 
trade courts shows that some international criminal courts could be constitutional. Thus, the evidence presented here can guide the tailoring of such courts' jurisdiction to avoid constitutional conflicts. In light of this evidence, noncriminal international tribunals seem far less problematic.

Aside from having precedential significance, the nineteenthcentury discussion of why joining such a court would be impermissible speaks directly to today's constitutional jurisprudence and helps draw lines between permissible and impermissible international delegations of judicial authority. It is also an untapped source of guidance on other leading constitutional questions, such as the domestic use of nonArticle III courts and the scope of and limitations on the treaty power.

Additionally, nearly every argument made today about American exceptionalism in international law and about the conflict between domestic and international law was rehearsed nearly two hundred years ago. America was accused abroad of xenophobia, arrogant exceptionalism, petty formalism, and indifference to massive human rights abuses. ${ }^{6}$ Domestically, there were arguments that the Constitution could not be interpreted in ways that would keep the country out of an emerging world order of international cooperation: everyone else had joined the treaty, and the United States' credibility as a human rights leader would be undermined if it did not participate. Even the idea of "lawfare" was anticipated by Americans who claimed that Britain was simply using international law and humanitarian concerns as a cover to advance its own naval dominance. ${ }^{7}$ The slave-trade-courts episode thus shows current issues in a context removed from today's political prejudices. ${ }^{8}$

${ }^{6}$ See, e.g., Matthew Mason, The Battle of the Slaveholding Liberators: Great Britain, the United States, and Slavery in the Early Nineteenth Century, 59 WM. \& MARY Q. 665, 671 (2002) (describing how "American officials' refusal to cooperate with Britain [in the right of search for slave-trade suppression] opened them to the charge of being sympathetic to the African slave trade").

7 See Diary Entry of John Quincy Adams (June 4, 1817) (calling the proposal for mutual search and capture of slave-trading vessels a "barefaced and impudent attempt of the British to obtain in time of peace that right of searching and seizing the ships of other nations which they have so outrageously abused during war"), in 3 MEMOIRS OF John Quincy Adams 555, 557 (Charles Francis Adams ed., Philadelphia, J.B. Lippincott \& Co. 1874) [hereinafter ADAMS MEMOIRS].

${ }^{8}$ It is not, however, free of past prejudices. While repression of the slave trade, unlike domestic abolition, was broadly popular in America, cooperation with the British was not. See infra text accompanying notes 85-98. The Article will attempt to tease out the effects of these attitudes from the constitutional arguments. See infra Part III. 
While the U.S. delegation negotiating the Rome Treaty, the instrument establishing the ICC, took constitutional issues into account, ${ }^{9}$ it was unaware that an earlier international tribunal had been rejected on constitutional grounds. ${ }^{10}$ Indeed, the entire fifty-year episode is absent from the growing scholarly literature on international tribunals and non-Article III courts, ${ }^{11}$ as well as from historians' discussions of American foreign relations and the slave trade. ${ }^{12}$ This omission is particularly significant because historical argumentsarguments based on the precedent of the mixed commissions created by the Jay Treaty in 1794-underpin contemporary arguments in support of the constitutionality of international tribunals. ${ }^{13}$ As one lead-

${ }^{9}$ See Scheffer \& Cox, supra note 5, at 986 n.7 (noting that "[c]onstitutional issues were constantly considered").

${ }^{10}$ See E-mail from David Scheffer to author (Sept. 7, 2009) (on file with author) (affirming that while serving as negotiator of the Rome Treaty on behalf of the United States, Scheffer did "not . . recall the issue of the slave trade courts being raised").

${ }^{11}$ The sole exception is a few paragraphs in Lee A. Casey \& David B. Rivkin, Jr., The Limits of Legitimacy: The Rome Statute's Unlawful Application to Non-State Parties, 44 VA. J. INT'L L. 63, 69-71 (2003). While the authors view the rejection of the British slavecourt proposal as a precedent against the ICC, however, they do not analyze the constitutional grounds for that rejection. See id. Moreover, the authors' description of the proposal as concerning "only a civil jurisdiction," $i d$., might obscure the actual basis for the United States' rejection. See infra subsection V.A.2 (noting the agreement that international criminal courts would be unconstitutional).

${ }^{12}$ For major works dealing with this period that neglect the episode, see DANIEL Walker Howe, What Hath God Wrought: The Transformation of America, 1815-1848 (2007); HOWARD JONES \& DONALD A. RAKESTRAW, PROLOGUE TO MANIFEST DESTINY: ANGLO-AMERICAN RELATIONS IN THE 1840S, at 72-81 (1997); BRADFORD PERKInS, Castlereagh AND AdAMS: ENGLAND AND THE UNITED STATES, 1812-1823 (1964); James A. RaWley With Stephen D. Behrendt, The Transatlantic Slave Trade (rev. ed. 2005); Hugh G. Soulsby, The Right of SEARCH AND the Slave TRADE IN ANGLO-AMERICAN RELATIONS, 1814-1862, at 174-76 (1933). While these historians mention that the United States balked at the mixed commissions, they devote less than one page to the issue. None discusses the nature or merits of the constitutional objections.

${ }^{13}$ See Henkin, supra note 5, at 266-70 (citing U.S. participation in a variety of mixed tribunals as evidence of the constitutionality of joining the ICC but not mentioning the United States' rejection of the slave-court treaty); Diane Marie Amann \& M.N.S. Sellers, The United States of America and the International Criminal Court, 50 AM. J. COMP. L. (SUPP.) 381, 382-85 (2002) (reviewing U.S. involvement in the development of international criminal adjudication); David Golove, The New Confederalism: Treaty Delegations of Legislative, Executive, and Judicial Authority, 55 STAN. L. REV. 1697, 1703-06 (2003) (tracing the pre-Founding Era precedents for modern international organizations); Henry Paul Monaghan, Article III and Supranational Judicial Review, 107 COLUM. L. REV. 833, 851-52 (2007) ("So far as practice can settle meaning, [the Jay Treaty] establishes that the United States can enter international agreements creating state-state arbitration panels to resolve the private law claims of its nationals against foreign governments.”); Edward T. Swaine, The Constitutionality of International Delegations, 104 CO- 
ing legal historian put it, the precedent established by the Jay Treaty commission has gone "unchallenged."

The only scholarship on the mixed courts examines the operation of the tribunals established by Britain with other nations; it does not examine the story of U.S. rejection. ${ }^{15}$ Professor Jenny Martinez has recently argued that the antislavery courts can be seen as an encouraging precedent for today's international human rights tribunals. According to Martinez, "the United States should consider . . supporting stable international legal institutions" like the ICC. ${ }^{16}$ Given her conclusions, it is surprising that she skips past the constitutional grounds for America's longstanding abstention from this international system. ${ }^{17}$

Whatever one generally thinks of the relevance of historical practice to contemporary legal questions, ${ }^{18}$ history is particularly relevant here because it has been heavily invoked in arguments suggesting that U.S. participation in international courts is constitutional. ${ }^{19}$ Moreover, the history presented in this Article, unlike most history, is relevant to a broad gamut of approaches to constitutional interpretation.

LUM. L. REV. 1492, 1532 (2004) (arguing that nondelegation objections "must confront the longstanding practice of employing international arbitral tribunals"); Wedgwood, supra note 5; see also RICHARD H. FALLON, JR. ET AL., HART AND WECHSLER'S THE FEDERAL COURTS AND THE Federal SYSTEM 50-51 (5th ed. Supp. 2008) (describing Monaghan's article as an "important contribution" whose "analysis rests largely on historical practice").

${ }^{14}$ Golove, supra note 13 , at 1746.

${ }^{15}$ See Jenny S. Martinez, Antislavery Courts and the Dawn of International Human Rights Law, 117 YALE L.J. 550, 579-95 (2008) (describing the antislavery courts that resulted from bilateral treaties between Britain and other countries); see also Edward Keene, A Case Study of the Construction of International Hierarchy: British Treaty-Making Against the Slave Trade in the Early Nineteenth Century, 61 INT'L ORG. 311, 312-15 (2007) (explaining the differences in the provisions of the treaties that Britain used to establish slave-trade tribunals with different nations).

${ }_{16}^{16}$ Martinez, supra note 15, at 640.

${ }^{17}$ See id. at 603 (mentioning President James Monroe's constitutional objection in less than a sentence: "Monroe ... objected to the mixed courts as 'incompatible' with the Constitution ...."); see also Jenny S. Martinez, Slave Trade on Trial: Lessons of a Great Human-Rights Law Success, BosTON REV., Sept.-Oct. 2007, at 12, 15 ("Concerns about both sovereignty and freedom of the seas prevented [the United States] from joining the mixed-courts regime....").

${ }^{18}$ See, e.g., Richard A. Posner, Past-Dependency, Pragmatism, and Critique of History in Adjudication and Legal Scholarship, 67 U. CHI. L. ReV. 573, 579 (2000); David J. Bederman, Foreign Office International Legal History 2-8 (Emory Univ. Sch. of Law Pub. Law \& Legal Theory Research Paper Series, Research Paper No. 05-24, 2005), available at http://papers.ssrn.com/sol3/papers.cfm?abstract-id=756886 (discussing the kind of legal historiography that makes for acceptable scholarship).

${ }^{19}$ See supra notes 13-14. 
The events took place at the last twilight of the founding generation. ${ }^{20}$ A few Framers were among the key participants in the episode, and others were still in Congress. ${ }^{21}$ There is no clear originalist evidence about the constitutionality of international criminal courts. It might be in keeping with the spirit of originalism, however, to look at how the immediate successors of the Framers understood the arrangements that the prior generation had made. And these were not ordinary successors. Indeed, John Quincy Adams, the central figure in the story, might be considered, like John Marshall, an honorary or quasi-member of the founding generation. $^{22}$

${ }^{20}$ These events are too far from the Framing to be direct originalist evidence. Legal historians sometimes treat the entire period up to 1815 as part of the Founding Era. See, e.g., Daniel Hulsebosch \& David Golove, On an Equal Footing: ConstitutionMaking and the Law of Nations in the Early American Republic 50 (Mar. 15, 2008) (unpublished manuscript presented at the Alberico Gentili Conference, NYU), available at http://www.law.nyu.edu/search/ECM_DLV_016254 (referring to "the founding generation" as spanning "from 1776 to about 1815 "). This Article's focus begins precisely where that period ends, with the Treaty of Ghent.

${ }^{21}$ The entire negotiation was presided over by James Monroe, who was the last Revolutionary War veteran elected President and who had been a member of the Continental Congress and the Virginia Ratifying Convention. He personally approved Adams's constitutional arguments. See 2 DANIEl Preston, A CoMPreHEnsive CataLOGUE OF THE CORRESPONDENCE AND PAPERS OF JAMES MONROE 734, 856, 888 (2001) (listing Monroe's supervisory correspondence with Calhoun and Adams on the issue). Albert Gallatin, at the time Minister to France, advised the Administration on the treaty. He had been a member of the 1789 Pennsylvania Constitutional Convention, which considered the first proposed amendments to the Constitution, and was one of the leading diplomats of the Founding Era. See Biographical Directory of the U.S. Congress, Gallatin, Albert, http://bioguide.congress.gov/scripts/biodisplay.pl?index=G000020 (last visited Oct. 15, 2009). Charles Pinckney, also a Framer, sat in the House from 1818 to 1821. Biographical Directory of the U.S. Congress, Pinckney, Charles, http://bioguide. congress.gov/scripts/biodisplay.pl?index=P000354 (last visited Oct. 15, 2009). Sitting in the Senate throughout the negotiations was Rufus King, one of the drafters of the Constitution. King had been ambassador to the Court of St. James and was involved with resolving the Jay Treaty controversies. He was also a leading advocate of the gradual abolition of the slave trade and was extremely active from 1817 to 1820 in opposing the introduction of slavery to new states. Cf. 6 THE LIFE AND CORRESPONDENCE OF RUFUS KING 90-95 (Charles R. King ed., 1900) [hereinafter KING]. Nevertheless, he vehemently opposed the slave-trade convention because of the search issue. See, e.g., PrESTON, supra, at 733 (noting a letter from King to James Monroe in which King voiced his opposition to the search proposal).

${ }^{22}$ Adams was not simply the son of a distinguished Framer. Though he joined his father on diplomatic missions in the Revolutionary period, his participation in the political debates at the dawn of the Constitution led George Washington to appoint him as Minister to the Netherlands at the age of twenty-six and to other diplomatic posts in the 1790s. See Paul C. NAgel, John Quincy Adams: A Public Life, A Private Life 1213, 73-77 (1998). These were not protocol posts for a scion of a powerful family: Adams was one of only five American ministers to foreign countries. See id. at 82 (explain- 
For an adherent of the traditional lawyerly method, one who cares about the patina put on the Constitution by practice and usage, more than forty years of consistent interpretation cannot be easily dismissed. Especially in the area of foreign relations, where judicial interpretations are few and far between, the considered conduct of the political branches is the stuff of which law is made. Finally, this history should speak to a pragmatic, policy-oriented view of the law. The diplomatic and human rights arguments made for and against U.S. participation in the slave-trade courts are nearly identical to those made about the ICC today.

Part I of this Article situates the debate over international courts as part of two broader constitutional debates-the scope of the treaty power and the permissibility of creating non-Article III courts. Part II tells how, during James Monroe's Administration, the United States rejected an intense diplomatic effort to persuade it to join a system of international courts concerned with the slave trade. While Part II chronicles the back-and-forth of this diplomacy, Part III disentangles the legal arguments, elucidating and evaluating the constitutional grounds adduced for the refusal. Part IV describes how in 1862, under the pressure of the Civil War, the United States agreed, with some important qualifications, to the British proposal for a right of search and mixed courts. Part V shows how even during the Civil War period there was generally agreement on the unconstitutionality of an international criminal court. It synthesizes the constitutional lessons of the entire history of negotiations and shows how they apply to modern international courts and to the ICC in particular. Important arguments in support of the ICC, such as the similarity of its procedure to extradition, are considered in light of the slave-trade-court precedent.

\section{Current Constitutional Debates}

This Part provides the background to the major constitutional debates that converge in the question of international courts. The nineteenth-century discussion of slave-trade courts reflects an approach to these questions that is surprisingly compatible with current constitutional thinking despite the many changes in constitutional law that have since transpired. A fuller understanding of these doctrines is needed, however, to better appreciate how these questions might have been viewed when they first arose in the early nineteenth century. 
The first question is the extent to which Congress must use Article III courts. International tribunals seem less objectionable if Congress can freely choose between assigning cases to Article III courts and other fora. Secondly, there are questions about the extent to which the aforementioned constitutional rules apply when Congress is legislating pursuant to a treaty. Justice Holmes famously established in Missouri $v$. Holland that the treaty power is unencumbered by federalism constraints. ${ }^{23}$ Yet treaties cannot override individual rights.

\section{A. Non-Article III Courts}

Article III of the Constitution vests the federal judicial power in "one supreme Court, and in such inferior Courts as the Congress may from time to time ordain and establish." ${ }^{24}$ The judges of these courts are appointed with the advice and consent of the Senate and hold their offices for life. Nonetheless, Congress has, from near the beginning of the Republic, allowed cases that fall within the scope of Article III to be heard by other types of tribunals in certain contexts. The use of such non-Article III courts grew considerably in the twentieth century as part of the rise of the administrative state. Nonetheless, the cases countenancing non-Article III courts make clear that their use is subject to significant limitations. They are not simply fungible substitutes for Article III courts.

\section{The Nineteenth Century: Territorial, Military, and Consular Courts}

The First Congress gave jurisdiction over crimes and disciplinary violations by soldiers to courts martial headed by commissioned officers instead of federal judges. ${ }^{25}$ The constitutionality of these courts martial appears to have been taken for granted by the founding generation. Indeed, courts martial were used throughout the Revolutionary War and were assumed to carry over into the constitutional system. $^{26}$ Generally, military courts are understood as being quite separate from the civilian judicial system. The Constitution often

${ }^{23}$ See 252 U.S. 416, 433 (1920) ("It is obvious that there may be matters of the sharpest exigency for the national well being that an act of Congress could not deal with but that a treaty followed by such an act could ....”).

${ }^{24}$ U.S. CONST. art. III, $§ 1$.

${ }^{25}$ See James E. Pfander, Article I Tribunals, Article III Courts, and the Judicial Power of the United States, 118 HARV. L. REV. 643, 715-16 (2004).

${ }^{26}$ Id. 
treats military matters as a unique category, and the applicable justice system is one of those matters.

After the Louisiana Purchase in 1803, Congress established governments for the newly acquired territories. This involved creating a full set of courts, including courts for the trial of criminal offenses and courts for common law cases that would hear matters otherwise heard by state courts. These courts were created outside of Article III, as were all future territorial courts. ${ }^{27}$

The constitutionality of these courts was first upheld in American Insurance Co. v. Canter. ${ }^{28}$ Justice Marshall's opinion did not suggest that Article III was optional. Rather, Article III had no application to the particular case of territorial courts. ${ }^{29}$ The territorial courts largely decided local matters that would normally be handled by state courts. In the territories, Congress exercised the power of both state and federal governments. ${ }^{30}$ To the extent that Article III sought to govern the division of authority between state and federal courts, its policy was inapplicable in the context of territories. ${ }^{31}$

Moreover, the territories were constituted with eventual statehood in mind. ${ }^{32}$ The temporary nature of territories is in obvious tension with the perpetual tenure of an Article III judge. If all territorial judges were appointed under Article III, the transition to statehood would leave many of them with nothing to do because state courts, with their judges chosen by the people, would take over much of the territorial judges' work. Additionally, giving a judge on a small-claims court a lifetime-tenured position would undermine the prestige of the federal judiciary.

An exception for "consular courts" in foreign countries was made in In re Ross. ${ }^{33}$ From the mid-1800s, the United States-following the lead of European countries-entered treaties with Muslim and Asian states that allowed U.S. diplomatic officials to mete out justice to Americans accused of crimes in those countries. The purpose of these

27 See id. at 749-54 (discussing the formation of territorial courts under Article I).

28 U.S. (1 Pet.) 511 (1828).

${ }^{29}$ Id. at 546.

${ }^{30}$ Id.

31 The territorial-courts precedent was extended to the unincorporated territories in the Insular Cases. See, e.g., Dorr v. United States, 195 U.S. 138, 149 (1904) (holding that the right to a jury trial, afforded in the states, did not apply in the territory of the Philippines). Similarly, the precedent was applied to the District of Columbia in Palmore v. United States, 411 U.S. 389, 402-05, 410 (1973).

${ }^{32}$ See Northwest Ordinance of $1787 \S 13$, reprinted in 1 U.S.C. at LVI (2006).

33140 U.S. 453 (1891). 
deals was to insulate Americans from the harsh justice of those countries, but the effect was to allow executive officers to preside over the trials of Americans, without any procedural protections of constitutional rights. Ross upheld these arrangements ${ }^{34}$ in a broad holding that rested on three arguments: First, the treaty power was not cabined by other constitutional constraints. ${ }^{35}$ Second, the Constitution itself did not apply extraterritorially. ${ }^{36}$ Because there could be no Article III court for foreign territory, the consul did not usurp any U.S. judicial authority. ${ }^{37}$ Third, the defendant could not be prejudiced by a consular-court trial: had the United States not entered into treaties with foreign countries allowing for such courts, American citizens would have been tried by local courts where they would have enjoyed far fewer rights and, indeed, been subject to cruel and inhuman treatment. $^{38}$ Since it would not be unconstitutional for the United States to allow an American abroad to be tried in a foreign court, surely the United States could try him before an American non-Article III court-the greater would include the lesser. ${ }^{39}$

One way of explaining these exceptions to the Article III norm looks to the underlying sources of congressional authority. Arguments for allowing non-Article III courts have stressed the plenary nature of the powers given to Congress over the implementation of treaties, the regulation of territories, the military, and the District of Columbia. The absolute nature of congressional control in these contexts has suggested to the Court that some other constitutional constraints do not apply. (Similarly, one might think that these powers are sources of authority alternate to the Inferior Tribunals Clause and thus not subject to its supremacy requirements. ${ }^{40}$ ) This view is ques-

34 Id. at 480.

35 See id. at 463 ("The treaty-making power vested in our government extends to all proper subjects of negotiation with foreign governments.”).

${ }^{36}$ Id. at $463-64$.

37 See id. at 464 .

${ }^{38} I d$. at 465 .

39 The case's first and second points have since been overruled, and it is unlikely that consular courts would be found constitutional today. See Boumediene v. Bush, 128 S. Ct. 2229, 2259 (2008) ("Even when the United States acts outside its borders, its powers are not absolute and unlimited but are subject to such restrictions as are expressed in the Constitution." (internal quotation marks omitted)); Reid v. Covert, 354 U.S. 1, 16 (1957) (plurality opinion) (“[N]o agreement with a foreign nation can confer power on the Congress, or on any other branch of Government, which is free from the restraints of the Constitution.").

${ }^{40}$ See U.S. CONST. art. IV, \$ 3, cl. 2 ("The Congress shall have Power to dispose of and make all needful Rules and Regulations respecting the Territory ... belonging to 
tion-begging. Congress also has plenary power over foreign commerce, but cases arising from the exercise of that power are not free from Article III.

\section{The Twentieth Century: Administrative Courts and Public Rights}

The Supreme Court has attempted to infer limitations on the use of non-Article III courts by examining situations in the early Republic where such courts were used, as well as general structural considerations. Unfortunately, this approach has led to the subject's notoriety as one of the most "vexed and confusing subjects in federal law." Examining the nineteenth-century precedents begs the question of whether uses of non-Article III courts were isolated exceptions, made in "extraordinary situations," to the general rule of Article III supremacy or whether they were evidence of a broader rule-that Congress could create courts outside Article III when it wanted to. ${ }^{42}$

The twentieth-century cases are a mess, alternately reflecting the mandatory and permissive views of Article III. Crowell v. Benson established the basic constitutionality of using administrative courts to determine cases in the first instance. ${ }^{43}$ The Court drew what would become an important distinction between so-called public and private rights: The former involve claims against the United States for money and certain civil regulatory actions, such as customs enforcement, brought by the United States. Private rights, by contrast, include anything that looks like a classic common law right, as well as criminal prosecutions. ${ }^{44}$ The distinction between public and private rights is not always clear, and it has been subject to serious criticism. ${ }^{45}$

the United States ...."); $i d$. art. I, $§ 8$, cl. 14 (“[The Congress shall have Power] To make Rules for the Government and Regulation of the land and naval Forces ....”); $i d$. art. I, $\S 8$, cl. 17 ("[The Congress shall have Power] To exercise exclusive Legislation in all Cases whatsoever ... over ... the Seat of the Government ....").

${ }^{41}$ McGinnis, supra note 3, at 1726.

${ }^{42}$ See DAVId P. CURrie, Federal Jurisdiction in A Nutshell 53 (4th ed. 1999) ("Thus the Congress, in exercising the powers confided to it, may establish 'legislative' courts ....").

285 U.S. 22, 50 (1932).

${ }^{44}$ See N. Pipeline Constr. Co. v. Marathon Pipe Line Co., 458 U.S. 50, 70 n.24 (1982) (plurality opinion) (noting that criminal prosecutions have always been treated as "private rights" cases).

${ }^{45}$ See, e.g., Martin H. Redish, The Federal Courts in the Political Order: Judicial JURISDICTION AND AMERICAN POLITICAL THEORY 93-94 (1991) (calling the goal of limiting judicial power to cases of private rights "absurd"). 
Perhaps because public rights do not involve the kind of matters for which one would traditionally be entitled to any kind of hearing, Congress can apparently entrust them to Article I tribunals. ${ }^{46}$ Private rights, on the other hand, can only be delegated to non-Article III tribunals under very limited circumstances. Such delegations generally involve narrow and technical questions in the context of a detailed, overarching regulatory scheme. ${ }^{47}$ Even "core" common law claims can be taken away piecemeal from federal courts as long as the removal is motivated by administrative and technical concerns rather than a desire to find a forum more sympathetic to congressional policy. ${ }^{48}$

Other cases have taken a more absolutist view of the Article III requirement. Northern Pipeline Construction Co. v. Marathon Pipe Line Co. held that public rights, territorial courts, and military courts were narrow, context-specific exceptions to Article III exclusivity rather than evidence that Congress may make courts outside of Article III whenever it so desires. ${ }^{49}$ Northern Pipeline thus struck down provisions of the Bankruptcy Act that allowed non-Article III bankruptcy judges to decide all state law claims involving an estate. ${ }^{50}$ Similarly, private-rights cases will often require a jury under the Seventh Amendment, and the Court has held that, even when Congress can take such cases away from the federal courts, Congress cannot take them away from a federal jury. ${ }^{51}$ Because legislative tribunals invariably operate without a jury trial, the Seventh Amendment consideration greatly limits Congress's ability to give Article I tribunals classic private-rights cases even when Article III does not pose a barrier.

Yet the Article III absolutism of Northern Pipeline was quickly limited by Commodity Futures Trading Commission v. Schor, which allowed a regulatory agency to decide a limited class of common law contract claims arising out of the same transaction as those regulatory claims that the agency was created to hear. ${ }^{52}$ Congress's goal of promoting

${ }^{46}$ Cf. Crowell, 285 U.S. at 50; FALLON ET AL., supra note 13, at 49 (referring to Pfander's argument that non-Article III tribunals have historically had as their subject matter disputes that lie outside the jurisdiction of Article III courts).

47 See, e.g., Commodity Futures Trading Comm'n v. Schor, 478 U.S. 833, 853-57 (1986) (finding that the grant of jurisdiction over certain common law counterclaims to the non-Article III Commodity Futures Trading Commission did not violate the Constitution).

${ }^{48}$ See id. at 853-55.

49 See Northern Pipeline, 458 U.S. at 70-71.

${ }^{50}$ Id. at 84-87.

51 Granfinanciera, S.A. v. Nordberg, 492 U.S. 33, 61-64 (1989).

${ }^{52}$ See Schor, 478 U.S. at $837,857$. 
administrative convenience and the limited scope of jurisdiction-the Court described the damage to Article III values as "de minimis"were crucial to the decision. ${ }^{53}$ Thus, Northern Pipeline seems to contradict much of Crowell, but Schor rejects Northern Pipeline.

\section{The Availability of Article III Review}

Even in the confused non-Article III court jurisprudence, some things remain clear. The acceptability of legislative courts for anything other than pure public rights is premised on the availability of appeal to an Article III court, especially for constitutional and jurisdictional questions. ${ }^{54}$ If appellate review is possible, the issue has not been entirely withdrawn from " $\mathrm{t}]$ he judicial power of the United States, ${ }^{, 55}$ greatly reducing Article III problems. Indeed, almost all federal issues can be determined in the first instance by state courts, which lack any Article III features. Yet these courts are reviewable by the Supreme Court. This suggests that Article III is satisfied if the judicial power extends to the federal question, at least in appellate form.

With one small exception, Congress has always made decisions by civilian non-Article III judges reviewable by and subordinate to those of their life-tenured counterparts. ${ }^{56}$ Starting with the courts established for the Louisiana and Mississippi territories in 1804 and 1805, all territorial-court systems were reviewable by the U.S. Supreme Court on roughly the same terms as district or state supreme courts-i.e., for federal-question issues, not purely local ones. ${ }^{57}$ The one exception was the first territorial-court system, which was established for the Northwest Territory; Congress did not provide for Supreme Court review of these courts' decisions, largely because it would be impractical

53 See id. at 856.

54 See id. at 853 (observing that the legal rulings of the administrative courts were still subject to de novo review by Article III courts); Crowell v. Benson, 285 U.S. 22, 44 (1932) (noting that parties could seek suspension of the legislative-court order by instituting proceedings in a federal district court).

${ }_{55}$ U.S. CONST. art. III, $\$ 1$.

56 See William Wirt Blume \& Elizabeth Gaspar Brown, Territorial Courts and Law: Unifying Factors in the Development of American Legal Institutions (pt. 1), 61 MICH. L. REV. 39, 75-78 (1962) (discussing appellate review of nineteenth-century territorial courts).

${ }^{57}$ Similarly, the D.C. courts, though created by Congress, are not reviewable on local issues. See Palmore v. United States, 411 U.S. 389, 396, 407-10 (1973) (holding that the Supreme Court did not have jurisdiction to hear an appeal regarding a "strictly local crime"). 
given the difficulties of travel to Washington. ${ }^{58}$ The Court apparently upheld this severe limitation on Article III review and its own supremacy in a cryptic one-sentence opinion in the early case of Clarke $v$. Bazadone. ${ }^{59}$ Yet even this decision left open the possibility of habeas review in cases of detention and the possibility of other supervisory writs. $^{60}$ In short, there is no precedent for the creation of permanent civilian courts to which the Supreme Court's writ does not run. ${ }^{61}$

\section{B. Non-Article III Juries}

In Granfinanciera, S.A. v. Nordberg, the Court approached the Article III issue from another angle, suggesting that while there may not always be a right to an Article III judge, use of a non-Article III tribunal does not suspend the Seventh Amendment right to a jury in civil suits. ${ }^{62}$ Presumably the same would be said about the Sixth Amendment

58 See Act of May 8, 1792, ch. 42, § 4, 1 Stat. 285, 286 (providing that one Supreme or Superior judge of the territories could hold court). This eliminated all direct review, but habeas may still have been a possibility in criminal cases. See Clarke v. Bazadone, 5 U.S. (1 Cranch) 212, 212-14 (1803) (quashing an appeal from a Northwest Territory court on the ground that Congress had not authorized such jurisdiction, despite arguments by George Mason that the Supreme Court's status as "supreme" and the mandatory language of Article III, Section 2 regarding appellate jurisdiction gave the Court inherent authority to supervise and correct all other courts, independent of any act of Congress). Clarke was issued one week before Marbury $v$. Madison, 5 U.S. (1 Cranch) 137 (1803), though it appears subsequently in the United States Reports. See Anne AShmore, Library, Supreme Court of the U.S., Dates of Supreme Court Decisions: United States Reports, Volumes 2-107, August Term 1791OCTOBER TERM 1882, at 4 (1997), available at http://www.supremecourtus.gov/ datesofdecisions.pdf. Thus, depending on how well established one thinks judicial review was before Marbury, Clarke can be understood as implying that the Court must accept Congress's jurisdictional allocations even if they are unconstitutional. After Clarke, Congress did not exempt any territorial court from appeal. See also Blume \& Brown, supra note 56, at 78 (describing Congress's concern with the territorial-court appeal issue as focused on attaining uniform decisionmaking).

${ }^{59}$ The case held that there was no statutory basis for issuing a writ of error to the territorial court. 5 U.S. (1 Cranch) at 214.

${ }^{60}$ Perhaps such writs as those of habeas and mandamus, which had independent statutory and, in the case of habeas, constitutional, sources could still be issued. Cf. Pfander, supra note 25, at 724-27 (describing such common law writs as important to maintaining supervisory control over lower tribunals, including tribunals outside Article III).

${ }^{61}$ Military courts have always been an exception. Even today, many criminal cases adjudicated by a court martial are not reviewable by any Article III court. See Bernie Becker, Military Appeal Process Is Challenged, N.Y. TIMES, Nov. 28, 2008, at A30 (describing a bill approved by the House but still pending in Congress that would allow $\mathrm{Su}-$ preme Court review of all courts martial).

${ }^{62} 492$ U.S. 33, 64 (1989). 
right to a jury in criminal cases. Because non-Article III courts lack juries, Granfinanciera may have practical implications quite similar to the mandatory view of Article III in Northern Pipeline. Since the jury-trial right only applies to criminal and common law cases, the Granfinanciera limitation also has echoes of the private-rights criterion.

The courts for Louisiana, Mississippi, and Florida, as well as for the territories acquired from Spain one hundred years later, did not feature juries. The Supreme Court upheld this arrangement because there was no history of juries in these places. ${ }^{63}$ Perhaps the people were not accustomed to or prepared for jury service and would not expect the benefit of a jury. Like territorial courts themselves, the exception was explicitly temporary, until American legal norms permeated the new territories. ${ }^{64}$ Military courts also lack juries, though trial by a panel of officers substitutes. ${ }^{65}$ When it comes to jury trials, the early territorial courts and courts martial are invariably regarded as atypical pockets rather than an illustration that the Sixth Amendment is optional or subject to a balancing test. ${ }^{66}$

\section{International Courts}

The treaty power allows for arrangements unencumbered by the limitations of enumerated powers and federalism, as evidenced by the Supreme Court's holding in Missouri v. Holland. ${ }^{67}$ However, treaties are not entirely immune from constitutional constraint. For example, legislation pursuant to treaties cannot negate individual rights guaranteed in the Bill of Rights, ${ }^{68}$ and perhaps by extension other express individual rights, protections, or limitations on governmental power.

${ }^{63}$ Dorr v. United States, 195 U.S. 138, 148-49 (1904).

${ }^{64} I d$.

${ }^{65}$ Pfander, supra note 25, at 716-17.

${ }^{66}$ Yet supporters of joining the ICC argue that these precedents show that even civilians can be tried for conduct that took place in the United States proper. See, e.g., Scheffer \& Cox, supra note 5, at 1041-47.

${ }^{67}$ See 252 U.S. 416, 433-35 (1920) (explaining that legislation implementing a treaty is not limited by Tenth Amendment concerns and need not be justified by a separate Article I power).

${ }^{68}$ See Reid v. Covert, 354 U.S. 1, 16 (1957) (plurality opinion) (“[N]o agreement with a foreign nation can confer power on the Congress, or on any other branch ... which is free from the restraints of the Constitution."); see also Boos v. Barry, 485 U.S. 312, 324 (1988) (noting that rules of international law do not trump the Bill of Rights); Curtis A. Bradley, The Treaty Power and American Federalism, 97 MICH. L. REV. 390, 412 (1998) (arguing that there is no indication that the Framers intended to exempt the treaty power from the general proposition that the powers delegated to the national government are limited and few). 
The precise limits remain unclear. ${ }^{69}$ Thus, whether constitutional objections to international courts can be avoided through the treaty power depends heavily on the nature of those objections.

Much of the precedent for the view that the treaty power allows for the creation of international tribunals independent of the $\mathrm{Su}$ preme Court stems from the commission created by the Jay Treaty of $1794 .^{70}$ Subsequently, extensive use was made of bilateral mixed arbitral commissions to liquidate disputes between the United States and another country as part of a diplomatic reconciliation. ${ }^{71}$ The Jay Treaty commissions could only hear claims against the British and U.S. governments, which had undertaken to compensate outstanding creditors from both sides and thus to remove an enduring source of friction. $^{72}$ These claims were "public rights." Claimants had no common law right to compensation from the countries themselves; the right was only granted by the treaty. Their right was only to pursue private claims in regular courts, because the money was not owed by the governments. Even if the money had been owed by the governments, suits would have been barred by sovereign immunity. Thus, from the perspective of the private American parties affected by the treaty-

${ }^{69}$ The debate goes back to the Founding Era. See John T. Parry, Congress, the Supremacy Clause, and the Implementation of Treaties, 32 FORDHAM INT'L L.J. 1209, 1211-12 (2009) (stating that there was "a lack of consensus [and] also considerable confusion about how the treaty power, legislative powers, and supremacy clause would interact under the new Constitution"). There are also notable recent contributions. Compare Bradley, supra note 68 , at 394-95 (arguing that the treaty power should not be construed so as to negate federalism), and Nicholas Quinn Rosenkranz, Executing the Treaty Power, 118 HARV. L. REV. 1867 (2005) (contending that Missouri v. Holland was wrongly decided), with David M. Golove, Treaty-Making and the Nation: The Historical Foundations of the Nationalist Conception of the Treaty Power, 98 MICH. L. REV. 1075, 1079 (2000) (maintaining that Missouri v. Holland was correctly decided), and David Sloss, International Agreements and the Political Safeguards of Federalism, 55 STAN. L. REV. 1963, 1975-88 (2003) (positing that federalism limitations need not be imposed on the treaty power).

${ }^{70}$ Treaty of Amity, Commerce, and Navigation, U.S.-Gr. Brit., Nov. 19, 1794, 8 Stat. 116 [hereinafter Jay Treaty].

${ }^{71}$ These tribunals have always had narrow purviews. For example, the Iran-United States Claims Tribunal, created in 1981 and based in The Hague, has purely retrospective jurisdiction over contract and property claims by U.S. nationals against Iran and its entities. See Dames \& Moore v. Regan, 453 U.S. 654, 664-66 (1981) (describing the creation of the Claims Tribunal).

${ }^{72}$ The commission established by Article VI of the Jay Treaty is certainly a very discouraging precedent. It had only one ignoble session, in which it decided nothing. The American commissioners were disappointed that the tie-breaking moderator, chosen by lot in case of a deadlock, was British. The Americans withdrew from the proceedings, defeating a quorum. See Samuel Flagg Bemis, JaY's Treaty: A Study in COMMERCE AND DiPLOMACY app. V, at 318 (1923). 
parties who would have otherwise been limited to suing in British courts-one group of non-Article III judges was replaced by another. ${ }^{73}$

Aside from such commissions, there has been little occasion to consider the extent to which participation in international tribunals might infringe upon constitutional principles because the United States has not joined such tribunals. ${ }^{74}$ The debate began in earnest only in the 1990s with the signing of the North American Free Trade Agreement (NAFTA), which allows certain U.S. administrative decisions to be challenged before a binational commission. Previously, these matters would have been heard by Article III courts, which now have very limited authority to review the rulings of the binational panels. ${ }^{75}$

\section{THE REJECTION OF MiXed COURTS}

This Part describes America's longstanding refusal to join an international network dealing with slave trading on the high seas. The focus here is the diplomatic history of the refusal; the subsequent Part explores the legal arguments. The understanding that joining such a system would be unconstitutional was apparently unanimous in the first half of the nineteenth century.

Starting in 1817, Britain entered treaties with numerous countries establishing international courts for the slave trade. ${ }^{76}$ Nevertheless, the United States maintained that the Constitution categorically forbade trying American citizens before such tribunals, which were com-

${ }^{73}$ This presages the "greater includes the lesser" reasoning employed in In re Ross. See supra notes 33-39 and accompanying text.

${ }^{74}$ The United States signed the Rome Statute of the International Criminal Court, but neither the Clinton nor the Bush Administration pursued ratification. In fact, President George W. Bush removed the United States' signature from the treaty, provoking an outpouring of criticism from international lawyers in Europe and America. See David Tolbert, International Criminal Law: Past and Future, 30 U. PA. J. INT'L L. 1281, 1289 (2009).

${ }^{75}$ Constitutional challenges to NAFTA tribunals remain unresolved. See, e.g., Coal. for Fair Lumber Imps., Executive Comm. v. United States, 471 F.3d 1329, 1332-33 (D.C. Cir. 2006) (per curiam) (ruling that a U.S.-Canadian settlement agreement precluded review of a panel ruling); Am. Coal. for Competitive Trade v. Clinton, 128 F.3d 761, 764-65 (D.C. Cir. 1997) (dismissing a suit for lack of standing where the petitioner "failed to establish the requisite causal connection between its alleged injury and the binational panel system”).

${ }^{76}$ See Martinez, supra note 15, at 552-53 ("Between 1817 and 1871, bilateral treaties between Britain and several other countries ... led to the establishment of international courts for the suppression of the slave trade... [They] involved as many as one out of every five or six ships involved in the transatlantic slave trade." (footnote omitted)). 
posed of one judge from each country. ${ }^{77}$ The mixed-courts proposal was part of a broader initiative under which countries agreed to allow their merchant ships to be searched on the high seas for evidence of participation in the slave trade. Vessels seized for involvement in the trade were brought before the mixed courts. ${ }^{78}$

Most of the relevant discussions between the United States and Britain took place between 1818 , when a treaty was formally proposed, and 1824, when efforts to achieve a more modest treaty broke down amidst British allegations of bad faith. While Britain imposed mixedcourts treaties on other countries over the subsequent decades-and continued to hold out hope, at a minimum, for a search treaty with the United States-mixed commissions were off the table. ${ }^{79}$

By happenstance, John Quincy Adams played a central role in the American response at every stage: he served as Minister to Britain when the slave-trade courts were first conceived, as Secretary of State during the most active period of negotiations, and ultimately as the President who supervised the negotiations to their unsuccessful conclusion. $^{80}$ He played the largest role in formulating the constitutional objections to the British project.

Adams's centrality is fortunate for historical purposes. First, his diaries are among the most meticulous of any statesman of the time. ${ }^{81}$ They provide the most thorough record of the considerations involved in the slave-courts matter. Second, he was (and still is) regarded as a man of extraordinary intellect and learning, easily the most brilliant statesman of the time, and a serious scholar of the Con-

${ }^{77}$ See id. at 579, 603-04 (explaining that President Monroe rejected international courts as disallowed by the Constitution).

${ }^{78}$ See id. at 582.

${ }^{79}$ See Leslie Bethell, The Mixed Commissions for the Suppression of the Transatlantic Slave Trade in the Nineteenth Century, 7 J. AFR. HIST. 79, 82-83 (1966) (describing Lord Palmerston's policy of expanding the anti-slave-trade treaty network and describing its success with every nation except the United States and France); see also THE FOREIGN Slave Trade: A Brief Account of Its State, of the Treaties Which Have BeEN ENTERED INTO, AND OF THE LAWS ENACTED FOR ITS SUPPRESSION, FROM THE DATE OF THE ENGlish AbOlition ACt to The PRESEnt Time 20 (London, John Hatchard \& Son et al. 1837) (bemoaning, with some exaggeration, the U.S. rejection "[y]ear after year" of "advances made by this country for a treaty for affording mutual facilities").

${ }^{80}$ Additionally, Adams's son, Charles Francis Adams, would later be the American envoy to the Court of St. James, when, under the pressure of the Civil War, the United States ultimately acceded to such a treaty. See infra Part IV (describing the circumstances surrounding the United States' accession).

${ }^{81}$ See Howe, supra note 12, at 245 (describing Adams's devotion to selfimprovement by setting aside time every day for diary writing). 
stitution. ${ }^{82}$ Adams was also a lifelong enemy of slavery. While in the Executive, he did not favor radical restrictions on slavery. He became more active, though, when he sat in the House of Representatives in the 1830s and 1840s. Indeed, he was a leading sponsor of petitions to abolish the slave trade in the District of Columbia, which earned him the wrath of his fellow Southerners and made him an early target of the gag rule. ${ }^{83}$ Most famously, he defended in the Supreme Court the slaves on board the Amistad who took over the ship that was transporting them after killing the officers and many of the crewmembers. ${ }^{84}$

\section{A. The Campaign Against the Slave Trade}

In the early 1800 s, a powerful movement to abolish the transatlantic slave trade arose in England and America. By 1815, a majority of Americans had come to regard slavery as evil, though many still thought it necessary or feared the social dislocations that emancipation could cause. ${ }^{85}$ Opposition to the slave trade was even stronger, based in part on a growing awareness across society of the massive death toll and great cruelty of the Middle Passage ${ }^{86}$ Measures against the transatlantic trade had broad support in Congress into the 1830s.

The issue of the transatlantic slave trade was quite distinct from the issue of domestic slavery. Abolition did not emerge as a significant movement until the 1830s, sparked in part by the Nat Turner revolt and South Carolina's nullification efforts in $1829-1830{ }^{87}$ Until then, measures to restrict the slave trade enjoyed the support of a robust "Baptists and bootleggers" coalition comprised of Quakers, other moral critics of slavery, as well as slave owners who did not wish to see the prices of their "property" undercut. Moreover, like the project to colonize Africa with freed slaves, ending the trade was seen by moderate Southerners as a way to gradually mitigate the evils of slavery without implementing radical changes. ${ }^{88}$ Indeed, Southerners were among the most vocal proponents of abolishing the transatlantic

${ }^{82}$ See id. at 244-45.

See id. at 512, 514.

${ }^{84}$ See id. at 521-22.

85 See id. at 53.

86 See id. at 51-52.

${ }^{87}$ For example, the New England Anti-Slavery Society first met in 1833, and the American Anti-Slavery Society, the most prominent American abolitionist group, formed over the next few years. Id. at 426 .

${ }^{88}$ See id. at 254. 
trade; the most prominent opponents of mixed courts were figures with impeccable antislavery credentials.

Thus, one cannot consider the proposed courts victims of the Slave Power. (Nothing in the discussions under the Monroe and Adams Administrations betrays any concern that the proposal was part of a creeping abolitionism.) Southerners only began to perceive a connection between the movement against the slave trade and abolition more generally in the 1840 s or 1850 s, as they increasingly bristled at any Northern interest in their "peculiar institution." From that point on, but not before, opposition to slave-trade courts in at least some sectors was difficult to disentangle from opposition to any initiatives implicitly critical of slavery.

In the United States, a ban on the importation of slaves went into effect in 1808, the earliest date permitted by the Constitution. ${ }^{89}$ In 1820, the United States enacted the world's most draconian anti-slavetrade legislation, declaring the slave trade a form of "piracy," punishable by death. ${ }^{90}$ The statute applied to "any citizen of the United States" engaged in the slave trade on any foreign vessel as well as "any person whatever" engaged in the slave trade on a vessel "owned in the whole or part ... [by] any citizen or citizens of the United States." ${ }^{91}$

At the same time, European powers, though slower to legislate against the slave trade, had begun to denounce it. Britain was the undisputed leader of this movement, banning the trade throughout its dominions in $1807 .^{92}$ After that, it was eager to see other nations accept the same restriction; otherwise, Britain's rivals would gain a competitive advantage by using cheap slave labor in their colonies. It began to use its formidable diplomatic clout to push for an international slave-trade ban and comprehensive methods of enforcement. ${ }^{93}$ At the Congress of Vienna, held at the end of the Napoleonic wars, Britain secured an international resolution condemning the slave trade. ${ }^{94}$ While Lord Castlereagh, the foreign minister, pushed for more robust

${ }^{89}$ See U.S. CONST. art. I, § 9, cl. 1 ("The Migration or Importation of such Persons as any of the States now existing shall think proper to admit, shall not be prohibited by the Congress prior to the Year one thousand eight hundred and eight ...."); Act of Mar. 2, 1807, ch. 22, 2 Stat. 426 (prohibiting the importation of people of color as slaves after January 1, 1808).

${ }^{90}$ See Act of May 15, 1820, ch. 113, $§ ~ 4-5,3$ Stat. 600, 600-01; see also infra Section II.D.

\footnotetext{
${ }^{91} \$ \$ 4-5,3$ Stat. at 600-01.

${ }^{92}$ See Bethell, supra note 79, at 79.

93 See id.

${ }^{94}$ See Martinez, supra note 15, at 574.
} 
measures there and at the Congress of Verona shortly thereafter, he only received another nonbinding declaration. ${ }^{95}$ In the coming years, Britain would push doggedly to get all other nations, one by one, to ban the slave trade.

\section{B. Rejecting the Mixed-Courts Proposal}

Britain first proposed an international-justice mechanism for slave traders during the negotiation of the Treaty of Ghent, which ended the War of 1812. In the proposed treaty, both countries would declare the trade to be piracy. ${ }^{96}$ This would allow suspects from either nation to be tried in the courts of the other. ${ }^{97}$ The American delegation promptly rejected the proposal. ${ }^{98}$ One commissioner, James Bayard, argued that because of piracy's unique jurisdictional consequencespiracy was the only offense to which universal jurisdiction had ever applied-"a nation might, if it pleased, make any ... act of its own subjects punishable as piracy by its own Courts, but no nation, and no two nations, could make that piracy which is not recognized as such by other nations." ${ }^{99}$ Albert Gallatin retorted that such treaties would not actually make the slave trade universally cognizable but only "assimilate" the new offense to piracy, just like the statutes of which Bayard spoke. $^{100}$

Around the same time, the British began advocating a system of international courts. In a December 1816 conversation with John Quincy Adams, then the U.S. envoy in London, Lord Castlereagh first broached the possibility of American participation. Any nation entering into the system would give the other nations the right to search its merchant vessels. As to those caught on suspicion of slave trading, Castlereagh proposed that

trial should be by Commissioners not exclusively of the capturing nation; that each of the powers ... appoint one "Commissaire Juge," and that whenever a capture was made it should be tried by the Commissary Judge of the capturing nation and one of the nation, under whose flag

95 See id. at 574-75.

96 See Diary Entry of John Quincy Adams (Dec. 10, 1814) (stating that, under the proposed treaty, slave trading "should be assimilated to piracy and it should be agreed to punish the offenders as pirates"), in ADAMS MEMOIRS, supra note 7, at 93, 96-97.

97 See id. ("[T] he [c] ourts of justice should be open in each of the two countries to the subjects and citizens of the other.").

98 See id. at 97-98 (noting that Bayard, Adams, and Clay opposed the idea).

99 Id. at 97 .

${ }^{100} I d$. 
the slave-trading vessel should be taken, and, if they could not agree, then to call in the Commissaire Juge of a third and indifferent party to decide. $^{101}$

Adams thought the suggestion was a trial balloon and let it float away.

Britain had greater success in bringing other countries on board. In 1817, Holland and Spain signed treaties providing for mixed tribunals, and negotiations with several other countries were under way. Having more support for the plan, Castlereagh broached it again with Richard Rush, Adams's successor in London, at the beginning of 1818. He formally invited the United States to join such a treaty on June 20, 1818. ${ }^{102}$ Castlereagh elaborated upon the vast evil of the trade, a point with which Rush and most of the Administration certainly agreed. International cooperation was needed to bring it to an end, he argued. Rush was sympathetic and wrote to Washington for instructions. $^{103}$

The Cabinet met on October 20, 1818, to discuss the proposal and rejected it in its entirety. ${ }^{104}$ The discussion focused on the right of search. The search issue was political dynamite in America because of its association with impressment-a practice where U.S. ships were stopped and "searched" for British seamen-over which the War of 1812 had just been fought. Britain's ongoing claim of a right to search in that context remained a top diplomatic priority and a source of intense national resentment. Thus, at the Cabinet meeting and subsequently, the search proposal dominated all discussions of the proposed treaty, both because of its intense emotional resonance and because the mixed courts were a logically subsequent issue. The courts would have no docket in the absence of mutual search.

Nonetheless, the mixed commissions were raised and opposed at the Cabinet meeting. While the search proposal was openly objected to for policy and emotional reasons, the problem with the mixed courts was constitutional-though the two most prominent members

${ }^{101}$ Diary Entry of John Quincy Adams (Dec. 23, 1816), in ADAMS MEMOIRS, supra note 7 , at $452,454-55$.

102 See Richard Rush, MEMORANDA OF A RESIDENCE AT THE COURT OF LONDON 3236 (Philadelphia, Lea \& Blanchard 1845) (describing and reprinting Castlereagh's letter to Rush inviting the United States to join the treaty).

${ }^{103}$ See id. at 39.

104 See Diary Entry of John Quincy Adams (Oct. 30, 1818) ("The opinion was unanimous that this proposal ought not to be acceded to."), in 4 MEMOIRS OF JOHN QuincY ADAMS 148, 151 (Charles Francis Adams ed., Philadelphia, J.B. Lippincott \& Co. 1875) [hereinafter ADAMS MEMOIRS]. 
of the Cabinet differed as to the constitutional defect. ${ }^{105}$ Attorney General William Wirt ${ }^{106}$ took the lead in arguing that "there was no constitutional authority in the Government of the United States to establish" such a court. ${ }^{107} \mathrm{He}$ offered several structural and nondelegation objections. ${ }^{108}$ Because the Constitution made no mention of such an exotic hybrid tribunal, he apparently thought Congress was without power to create it. Adams rejected this reasoning, citing the precedent of the Jay Treaty commission and the broad scope of the treaty power. However, at the end of the meeting, the Cabinet voted unanimously against the proposal. Adams wrote Rush that the Administration viewed the mixed courts as unconstitutional because of the nondelegation issues raised by Wirt. ${ }^{109}$

\section{Not Taking "No" for an Answer}

Rush met with Castlereagh to outline the Administration's objections. The Foreign Minister was apparently surprised by the constitutional obstacle. Rush, however, reminded him that Britain had recently refused to enter the Holy Alliance-an early attempt at a European union among the victors of the Napoleonic wars-because of constitutional scruples. ${ }^{110}$ As Rush tells it, the point scored home: Castlereagh "candidly admitted that we, too, doubtless had our constitutional embarrassments" that would have to be overcome "by proper modifications of the plan." ${ }^{111}$ Seeing the depth of the Administration's opposition, Castlereagh decided to transfer the negotiations to

${ }^{105}$ For a thorough examination of the Cabinet's precise constitutional objections, see infra Part III.

${ }^{106}$ Wirt was the longest-serving and most influential Attorney General in the nation's history-serving for twelve years. Through his prolific use of opinion letters, he defined the office's paramount role in setting a consistent legal policy for an administration. See generally Henry M. Dowling, William Wirt, 10 GreEN BAG 453 (1898) (profiling Wirt); H. Jefferson Powell, William Wirt E the Invention of the Public Lawyer, 4 GREEN BAG 2D 297 (2001) (discussing Wirt's aspirations and impact on legal policy).

${ }^{107}$ Diary Entry of John Quincy Adams, supra note 104.

${ }_{108}$ See infra notes 165-72 and accompanying text.

109 See Letter from John Quincy Adams to Albert Gallatin and Richard Rush (Nov. 2, 1818), as reprinted in 5 AMERICAN STATE PAPERS: FOREIGN RELATIONS 72, $72-73$ (Asbury Dickins \& James C. Allen eds., Washington, D.C., Gales \& Seaton 1858) [hereinafter AMERICAN STATE PAPERS].

${ }^{110}$ See RUSH, supra note 102, at 215 ("I adverted to what Liverpool said[,] . . . that as the signatures of European Sovereigns to the Holy Alliance were all by their own hands, England could not join in it, as the Prince Regent was restrained, by the fundamental doctrine of the British constitution.").

${ }^{111}$ Letter from Richard Rush to John Quincy Adams (Nov. 10, 1819), as reprinted in AMERICAN STATE PAPERS, supra note 109, at 74, 75. 
Washington, where they would be conducted by Stafford Canning, the new British ambassador. ${ }^{112}$

\section{A Second Cabinet Meeting}

The British were relentless in their efforts to secure U.S. participation. In 1819 and 1820, the British, usually in the person of Canning, pressed the subject at every opportunity in a series of meetings with Adams. ${ }^{113}$ In these animated discussions, Canning argued that other European powers had joined such treaties without any objections. ${ }^{114}$ Canning hinted that America's refusal of a plan agreed upon by Europe could be seen as a "general . . . refusal to co-operate with them in any measure." 115 He also elaborated on the evils of the slave trade: would the United States not live up to its stated commitment to human rights? In reply, Adams repeatedly insisted that the right of search was politically untouchable and that the mixed commissions were legally so. He stressed the "incompatibility of such tribunals with the essential character of the constitutional rights guarantied [sic] to every citizen of the Union." hashed repeatedly, to the point of straining Adams's patience. ${ }^{117}$

${ }^{112}$ Proclamation of President James Monroe (Jan. 26, 1823), in AMERICAN STATE PAPERS, supra note 109, at 214, 214-15.

${ }^{113}$ See Diary Entry of John Quincy Adams (Apr. 14, 1819) (recounting a meeting with the British ambassador, Mr. Bagot, during which Adams referred to the nonimpeachability of the judges as a constitutional objection), in ADAMS MEMOIRS, supra note 104, at 333, 335; Diary Entry of John Quincy Adams (Oct. 2, 1820) (describing a two-hour conversation with Canning), in 5 ADAMS MEMOIRS, supra note 104, at 181, 181-82; Diary Entry of John Quincy Adams (Oct. 20, 1820) (recording a three-hour discussion), in 5 ADAMS MEMOIRS, supra note 104, at 189, 189; Diary Entry of John Quincy Adams (Oct. 26, 1820) (describing a two-hour discussion), in 5 ADAMS MEMOIRS, supra note 104, at 191-93; Diary Entry of John Quincy Adams (Dec. 18, 1820) (recounting another long meeting), in 5 ADAMS MEMOIRS, supra note 104, at 212, 214. Each of these conversations dealt extensively with the constitutional issues.

${ }^{114}$ See Diary Entry of John Quincy Adams (Oct. 2, 1820), supra note 113, at 182, 184. To this, Adams replied that broad European participation only strengthened his desire to stay out of the treaties, as the United States did not want to become entangled in the arrangements of a federative Europe. Id. at 182.

${ }^{115} I d$. at 183 .

${ }^{116}$ Letter from John Quincy Adams to Stratford Canning (Dec. 30, 1820), in AMERICAN STATE PAPERS, supra note 109, at 76, 76.

${ }^{117}$ See Diary Entry of John Quincy Adams (Oct. 26, 1820), supra note 113, at 192-93 ("I told him that it was not my wish to debate the point. We had more than once exhausted the argument with his Government...."). 
After these fruitless discussions, Canning prevailed upon Adams to put the question to the Cabinet again. ${ }^{118}$ Surprisingly, Monroe agreed, and the Cabinet revisited the issue on December 23, 1820. ${ }^{119}$ Again, much of the discussion focused on the right of search. ${ }^{120}$ This time Adams did not repeat his earlier defense of the commissions. Rather, " $[t]$ he opinion was unanimous ... that it would be repugnant to the article in the Constitution concerning the organization of the judicial power." ${ }^{21}$ Adams might have voted with the Cabinet to avoid revising a settled position-or he may have come to see the proposal as unconstitutional on other grounds. ${ }^{122}$

\section{Trading Canada for Commissions?}

The campaign against the slave trade was a key part of British foreign policy. America's refusal to join the search treaties frustrated the goal of universal participation by maritime powers. Thus London, despite the initial rebuffs, continued over the next several years to press for the United States to join the mixed-courts regime. Adams complained that Britain was "using every exertion with unwearied importunity to obtain the assent to it of all the great European powers and of the United States." ${ }^{\prime 23}$

${ }^{118}$ Cf. Diary Entry of John Quincy Adams (Dec. 18, 1820) (describing Canning's urgings to Adams to have the President reconsider the proposal), supra note 113, at 214.

${ }^{119}$ Diary Entry of John Quincy Adams (Dec. 23, 1820), in 5 ADAMS MEMOIRS, supra note 104, at 216. The Cabinet met yet again one week later to approve the text of Adams's memorandum to Canning on the subject; again, there was consensus that the courts were unconstitutional. See Diary Entry of John Quincy Adams (Dec. 30, 1820) (" $[\mathrm{M}] \mathrm{y}$ draft of an answer to Mr. Canning ... was approved, with the suggestion of some slight alterations ... to soften the harshness of refusal."), in 5 ADAMS MEMOIRS, supra note 104, at 222, 222.

${ }^{120}$ Only Secretary of the Navy Smith Thompson favored the search provision. Thompson had previously been Chief Justice of the New York Supreme Court. He thought the search for slavers was a specific enough question that it would not serve as precedent for impressment but that "by declining [the search provision] we shall expose ourselves to the imputation of insincerity as to our purpose of suppressing the trade," which would "discredit us with the rest of Europe." Diary Entry of John Quincy Adams (Dec. 23, 1820), supra note 119, at 217. Nonetheless, Thompson thought that any slavers caught by British cruisers would have to be "tried by our own Courts." Id. Soon after, Thompson was appointed to the U.S. Supreme Court, where he served twenty years.

${ }^{121} I d$.

${ }^{122}$ See infra subsection III.A.2, Section III.B.

${ }^{123}$ Diary Entry of John Quincy Adams (Dec. 23, 1820), supra note 119, at 216; see also Letter from Albert Gallatin to James Monroe (Feb. 4, 1822) ("The total suppression of that traffic has become such a popular topic in England that the Ministers are compelled to follow the stream, and to use everywhere every possible endeavor to ob- 
Albert Gallatin, at the time Minister to France, suggested that Britain would be willing to make major concessions on other fronts-such as a northern adjustment of the United States' border with Canada and the opening of trade access to the West Indies markets-in exchange for U.S. agreement to the slave-trade treaty. ${ }^{124}$ Gallatin thought this was an opportunity worth exploring, particularly with regard to the West Indies markets, which he saw as more important for the United States than adjusting the northern border. ${ }^{125}$ However, he cautioned that Washington would first have to secure "modifications ... which would render [the slave-trade convention] admissible."

The possibility of gaining territorial and trade benefits in exchange for the slave-trade treaty may seem remarkable. Yet there are reasons to believe that the possibility was not just an uncharacteristic flight of fancy on the part of the veteran diplomat. ${ }^{127}$ Britain had previously bought Spain's and Portugal's participation in slave-trade treaties with gold. ${ }^{128}$ The United States would presumably need greater inducement than did the cash-strapped Iberian kingdoms. Moreover, the slave-trade and border issues were explicitly linked in the WebsterAshburton Treaty of 1842, which suggested their fungibility. ${ }^{129}$ The persistence of British offers and its willingness to make significant territorial and diplomatic concessions on other fronts suggests that the United States' refusal was truly rooted in intractable constitutional objections rather than political ones. The British apparently understood that the constitutional objections were in earnest and sought to work

tain from other nations their assent to some measure tending to produce the desired effect."), in 2 The Writings of Albert Gallatin 231, 232 (Henry Adams ed., Philadelphia, J.B. Lippincott \& Co. 1879).

${ }^{124}$ See Letter from Albert Gallatin to James Monroe, supra note 123, at 232 (" $[\mathrm{I}] \mathrm{t}$ would not be impossible to obtain, in consideration [of a modified slave-trade treaty], some favorable adjustment of other concerns.").

${ }^{125}$ See id. at 233 (describing as "worthy of consideration" the possibility of agreeing to the treaty in exchange for concessions in the West Indies).

${ }^{126} I d$.

127 See, e.g., Letter from Thomas Jefferson to James Madison (Nov. 15, 1823) (listing the agenda for negotiations with the British as including, according to Rush, suppression of the slave trade and the northern boundary), in 12 THE WORKS OF THOMAS JEFFERSON 325, 325 \& n.1 (Paul Leicester Ford ed., 1905).

${ }^{128}$ See Holger Lutz Kern, Strategies of Legal Change: Great Britain, International Law, and the Abolition of the Transatlantic Slave Trade, 6 J. HIST. INT'L L. 233, 242-43 (2004).

${ }^{129}$ See Treaty to Settle and Define the Boundaries Between the Territories of the United States and the Possessions of Her Brittanic Majesty in North America; for the Final Suppression of the African Slave Trade; and for the Giving Up of Criminals, Fugitive from Justice, in Certain Cases, U.S.-Gr. Brit., arts. I-III, VIII, Aug. 9, 1842, 8 Stat. 572. 
around them. ${ }^{130}$ None of these workarounds, however, addressed the central U.S. objections. Thus, Adams continued to insist that the "want of Constitutional authority to establish such a Court" was "decisive."131

\section{Congress's Views}

The constitutional doubts about mixed courts were shared by Congress. To be sure, the issue received less discussion in the Capitol than in the White House because the issue never progressed from the diplomatic stage to one at which the legislature could act on it. However, as far as the views of Congress can be determined, its members concurred in or deferred to the Administration's constitutional doubts. This is particularly significant because the House was much more favorably inclined than the Administration to join the British against the slave trade.

In the 1810 s and 1820 s, the slave-trade issue was high on Congress's agenda. Congress passed several restrictive laws, culminating with the 1820 legislation establishing the death penalty for slave trading. ${ }^{132}$ Congress followed the Administration's negotiations with London closely and was aware of the arguments. ${ }^{133}$ Most in Congress apparently favored some kind of agreement with Britain and other powers for the suppression of the trade. ${ }^{134}$ Two separate committees of the House considered the slave-trade issue in two consecutive Congresses.

Having reviewed the diplomatic correspondence, the House formed a special committee in December 1820 to "make a summary review of the Constitution" as it bore on the "proposed co-operation to exterminate the slave trade." cused on the right of search. Going against the views of the Administration, the committee endorsed the idea of mutual search on the

${ }^{130}$ Canning offered to have one of the two tribunals sit in the United States-which would partially answer the objection to extraterritorial courts-and to make the U.S. commissioners impeachable by Congress. Diary Entry of John Quincy Adams (Oct. 2, 1820), supra note 113, at 182 ; Diary Entry of John Quincy Adams (Oct. 20, 1920), supra note 113 , at 190 .

131 Diary Entry of John Quincy Adams (Oct. 2, 1820), supra note 113, at 182.

${ }^{132}$ See supra text accompanying note 90.

133 See, e.g., Diary Entry of John Quincy Adams (Jan. 9, 1821) (explaining how the House reviewed the full diplomatic correspondence on a slave-trade treaty), in 5 ADAMS MEMOIRS, supra note 104, at 231, 232-33.

${ }^{134}$ This can be inferred from the treatment of the 1824 search treaty, which was ratified by the Senate, albeit with reservations, and promoted by several resolutions in the House.

13537 ANNALS OF CONG. 1064 (1821). 
ground that it was "indispensable to the great object of abolition" of the transatlantic trade and noted that Britain's motives in seeking the arrangement were sincere rather than a pretext for entrenching British naval dominance. ${ }^{136}$ Thus, the hotly contested issue of search was, for the committee, a question of expedience, not one of principle. ${ }^{137}$

Not so for the mixed courts, which the committee rejected because of constitutional doubts. ${ }^{138}$ The committee suggested that instead of mixed tribunals, American vessels captured by the British should be returned to the United States for trial. ${ }^{139}$ While the report never flatly endorsed the Administration's constitutional arguments, it quoted them favorably and at great length. At no point did the committee or anyone else in Congress advocate mixed courts or even question the constitutional objections. ${ }^{140}$

A report by the committee on the abolition of the slave trade in the following Congress came to identical conclusions. That committee also urged joining with Britain to search vessels on the high seas. The committee noted that a proposal limited to a search treaty was free of the objections to the original British offer because the new proposal "contemplate[d] the trial and condemnation of such American citizens as may be found engaged in this forbidden trade, not by mixed tribunals sitting in a foreign country, but by existing courts, of competent jurisdiction, in the United States." ${ }^{141}$

Both reports recommended resolutions urging the President to negotiate with foreign powers toward a system for abolishing the international slave trade, and these resolutions were overwhelmingly

${ }^{136}$ See id. at 1069 ("The proposal itself . . . is a total abandonment, on the part of England, of any claim to visit and search vessels in a time of peace . ...”).

${ }^{137}$ See id. at 1070 ("[T] he reciprocal right ... is reduced to the simple inquiry whether, in practice, it will be beneficial to the two contracting nations.").

${ }^{138}$ See id. at 1068 (citing a letter from the Secretary of State expressing doubt that the U.S. government had the constitutional right to establish a court with foreign judges unaccountable to the U.S. appeals process and unable to be impeached).

139 See id. at 1070 ("[A]n arrangement perhaps could be effected so . . vessels and slaves delivered to the jurisdiction of the United States might be disposed of in conformity with the provisions of our own act ....").

${ }^{140}$ There was little other discussion of the constitutional issue. In one House debate, Representative Wright urged the Administration to take action in entering a slave-trade treaty, opining that "if it shall be found that [the treaty provisions] cannot be exercised under our Constitution, ... . it may be so altered as to leave no impediment to so desirable an object." 40 ANNALS OF CONG. 332 (1822).

14139 ANNALS OF CONG. 1537 (1822). 
approved by the House. ${ }^{142}$ The reports themselves were not voted on by the full House, which leaves open the possibility that the legislature did not endorse all of their particulars. ${ }^{143}$ Nonetheless, when the resolutions proposed by the report were debated, even those in Congress who strongly advocated allowing a right of search acknowledged that constitutional concerns required devising some workaround for the mixed courts. ${ }^{144}$

\section{E. Commissions Overboard}

By mid-1822, negotiations with the United States were dead in the water. Nevertheless, the British continually renewed their efforts. ${ }^{145}$ Canning suggested that Britain was open to more substantial amendments to the courts proposal, but he was yet again rebuffed by Adams because the former had suggested no "substitute for the mixed [c] ourts." ${ }^{146}$ Adams was feeling increased pressure from the House,

${ }^{142}$ See 40 ANNALS OF CONG. 1151-55 (1823) (approving the resolution by a vote of 131 to 9 ). After the failure of this round of negotiations, the House passed yet another resolution, to the same effect, in 1831. See 7 REG. DEB. 850 (1831) (passing, by a vote of 118 to 32, a resolution "request[ing the President] to renew and to prosecute from time to time such negotiations with the several maritime Powers of Europe and America ... for the effectual abolition of the African slave trade, and its ultimate denunciation, as piracy ... by the consent of the civilized world").

${ }^{143}$ Certainly some members felt that agreeing to the right of search itself went too far. Representative Forsyth of Georgia, one of the nine members who voted against the 1821 and 1822 resolutions, argued that

[committee] reports ... are nothing, until acted upon by the House, but the opinions of so many members of the House, who approve them... [A]t this session, a correspondence had been laid before this House which had taken place between this Government and the British Government, in which an argument was founded on certain expressions in a report of a committee of this House. .. I I protest against the opinion of a committee of this House being taken as an expression of the will of the House, unless first sanctioned by a vote of the House. . . I I for one, . . . believe the Senate acted right in refusing their assent to parts of that convention ....

1 REG. DEB. 626 (1825).

${ }^{144}$ Compare 40 AnNAls of CONG. 1153 (1823) (statement of Rep. Wright) (advocating a "qualified right of search" by the British), with 40 ANNALS OF CONG. 332 (1822) (statement of Rep. Wright) (expressing hope that if the British proposal "cannot be exercised under our Constitution, ... it may be so altered so as to leave no impediment to so desirable an object").

${ }^{145}$ See 42 ANNALS OF CONG. app. at 3003 (1823) (letter from Stratford Canning to John Quincy Adams) (stating that "His Majesty's Ministers are still unwilling to despair of finding the United States at length prepared" to join "the system of concert" previously proposed).

146 Diary Entry of John Quincy Adams (June 29, 1822), in 6 AdAMs MemoIRs, supra note 104 , at $35,35-36$. 
however, to work out some kind of international agreement regarding the slave trade. ${ }^{147}$ Finally, a frustrated Canning, in April 1823, sarcastically proposed jettisoning the mixed courts in favor of purely British ones. $^{148}$ If the United States objected to a novel international tribunal, surely it could not challenge the constitutional legitimacy of having slave traders tried solely by the British Admiralty courts. After all, the Jay Treaty had provided for extradition to Britain of certain U.S. criminals.

Canning's proposal was not meant to be taken seriously-he knew the United States would never agree to such a one-sided arrangement. But something in the idea-national courts instead of mixed commissions-was reflected in a compromise position that emerged in 1822 and 1823. It is not clear where this idea first arose, but by 1823 both the House He $^{149}$ and certain figures in the Monroe Administration thought the deadlock over prosecution could be broken by requiring captured offenders to be sent to their home countries for trial. ${ }^{150}$ While far from the British proposal, it would allow the United States to at least participate in the joint search aspect of the treaty. Adams formally submitted the counteroffer to Canning in March 1823, noting that it would be "a substitute for . . . trial by mixed commissions, which would be rendered useless by it."151 The British agreed, and a convention was signed and submitted to the Senate.

147 See Diary Entry of John Quincy Adams (June 20, 1823) (describing "views unfriendly to [the] Administration, and personally so to [Adams,]" coming from members of Congress), in 6 ADAMS MEMOIRS, supra note 104, at 149, 150; Diary Entry of John Quincy Adams (June 19, 1823) (reporting how Adams argued before the Cabinet that the Administration should "carry into effect the resolution of the House of Representatives recommending negotiation to obtain the recognition of the slave-trade to be piracy by the law of nations"), in 6 ADAMS MEMOIRS, supra note 104, at 148, 148. It is not clear why Adams felt so constrained by the nonbinding resolution of the House in an area of Executive supremacy. In any event, he was certainly amply rewarded for his solicitude of the people's representatives when they elected him President in 1825.

148 See 42 ANNALS OF CONG. app. at 3006-10 (1823).

149 See Comm. ON the SupPrESSION OF THE Slave Trade, 17Th CONG., REPORT OF THE COMmitTeE ON THE Suppression OF THE SlAVE TrADE 3 (1822), available at http:/ / digital.library.cornell.edu/cgi/t/text/text-idx?c=mayantislavery;idno=28893027 (follow "View Pamphlet or Book" hyperlink) (noting that the constitutional "objections apply ... to a particular proposition" that includes use of mixed courts rather than to the modified proposal that would use "existing courts, of competent jurisdiction, in the United States").

${ }^{150}$ See Letter from Albert Gallatin to John Quincy Adams (Jan. 18, 1823), in THE WRITINGS OF ALBERT GALLATIN, supra note 123, at 264, 265 (suggesting that the right of search, with rendition of detained vessels to the home country, would be an acceptable alternative to the constitutionally problematic mixed-court proposal).

15142 ANNALS OF CONG. app. at 3005 (1823). 
Adams had only pursued the treaty because of pressure from the House. He feared that the treaty would set a precedent for British meddling on the high seas. ${ }^{152}$ However, even with the mixed-courts provisions removed and certain other concessions requested by Adams already made by Britain, the treaty proved highly controversial in the Senate. In May 1824, the Senate gave its consent, but it did so only after making numerous reservations. ${ }^{153}$ Perhaps the most significant of these was limiting the right of search to the coast of Africa, barring it from the American coast. This made the treaty much less useful to the British, who already had a squadron stationed off of the African coast. The British saw this watered-down ratification as a back-handed rejection of the treaty, ${ }^{154}$ a view in which they were no doubt justified. ${ }^{155}$

The Senate's opposition to any concession on the right of search was made clear a few months later, when the Administration negotiated a slave-trade treaty with Colombia incorporating all the Senate's reservations to the failed British convention. Nonetheless, the Senate also rejected the Colombian convention, though the prospect of search by Colombian vessels was quite remote ${ }^{156}$ thereby demonstrating that the Senate was not prepared to make any concessions on the right of search. The British and American governments saw further negotiation as futile, and the diplomatic correspondence was officially

152 See Memorandum from Rufus King (May 23, 1824), in KING, supra note 21, at 572-73 (describing Adams's initial hesitation in agreeing to search on the high seas). He had insisted, as a condition of signing a search treaty, that Britain enact legislation mirroring America's 1820 act, declaring the slave trade to be piratical. See Diary Entry of John Quincy Adams (June 19, 1823), supra note 147, at 148-49. This ensured that any search exercised by Britain would not establish a general right of search on the high seas but rather would be incident to the established right to search for pirates.

153 See AMERICAN STATE PAPERS, supra note 109, at 361-62 (recording the Senate vote on ratification of the 1824 treaty).

${ }^{154}$ See Letter from George Canning to Richard Rush (Aug. 27, 1824) (noting British disapproval of the amended treaty), in AMERICAN STATE PAPERS, supra note 109, at 364.

155 See Letter from Rufus King to Charles King (May 22, 1824) ("The Senate has advised the Ratification of the Convention with Great Britain for the suppression of the Slave Trade upon conditions that will defeat the same; in other words they have rejected it.”), in KING, supra note 21, at 571.

156 See 2 REG. DEB. app. at 38 (1826) (noting the rejection of the Colombian Convention, even though "the coasts of America were excepted from its operation"); W. Stull Holt, Treaties Defeated by the Senate: A Study of The STRugGle Between PRESIDENT AND SENATE OVER THE CONDUCT OF FOREIGN RELATIONS 50-51 (1933)(discussing the politics of the Colombian treaty rejection and noting that it was the first treaty entirely rejected by the Senate). 
suspended in $1825 .^{157}$ Nonetheless, international agreements to suppress the slave trade, featuring both the right of search and mixed courts, remained a key part of British foreign policy in the following decades. $^{158}$ After the disappointment and betrayal of the 1824 treaty had faded somewhat, subsequent British governments again made overtures to the United States, in the 1830s, then again in the years leading up to the Webster-Ashburton treaty of 1842, ${ }^{159}$ and even as late as 1862. The British desire to achieve a treaty apparently never flagged.

The subsequent negotiations, and the attendant domestic political debates, focused on the right of search. Not surprisingly, mixed commissions were not featured explicitly in these negotiations. Commissions could only come into play if the parties agreed to a mutual right of search. Given the decisive rejection of the search treaty, as well as the overwhelming opposition to renewed search proposals in the early 1840 s and again in the late $1850 \mathrm{~s},{ }^{160}$ the commissions were off the table

157 See 2 REg. DEB. app. at 39 (1826) (letter from Henry Clay to Henry Addington) (" $[\mathrm{I}] \mathrm{t}$ would seem to be unnecessary and inexpedient any longer to continue the negotiation respecting the Slave Convention ....”).

${ }^{158}$ See Charles Sumner, Final Suppression of the Slave Trade, Speech in the Senate on the Treaty with Great Britain (Apr. 24, 1862) ("Not disheartened by failure with the United States, Great Britain pursued her honorable policy, enlisting Government after Government ...."), in 6 THE WORKS OF CHARLES SumNER 474, 481 (Boston, Lee \& Shepard 1872) [hereinafter SUMNER]; Martinez, supra note 15, at 595 (listing treaties with Brazil, Chile, the Argentine Confederation, Uruguay, Bolivia, and Ecuador).

${ }^{159}$ See DANiel Webster, The Diplomatic AND OfFicial PaPers of DANiEl WebSTER, at xix (New York, Harper \& Bros. 1848) ("Attempts were made on the part of England, during the ministry of Lord Melbourne, to renew the negotiation with the United States, but without success."). Certainly there was still strong support in the House for such arrangements. In 1831, Colonel Mercer offered, and the House passed by an overwhelming vote, yet another resolution calling on the President "to renew and to prosecute ... negotiations with the several maritime Powers ... for the effectual abolition of the African slave trade, and its ultimate denunciation, as piracy, under the law of nations." 7 REG. DEB. 850 (1831).

${ }^{160}$ See, e.g., 38 House J. 485, 486 (1843) (message of President John Tyler) (denouncing British efforts to search U.S. ships suspected of slave trading as an "arbitrary and ever-varying system of maritime police"); 33 SEN. J. app. 689, 693 (1842) (message of President John Tyler) ("The examination or visitation of the merchant vessels of one nation, by the cruisers of another, for any purpose [with certain exceptions] ... may lead to dangerous results. ... Interference with a merchant vessel by an armed cruiser, is always a delicate proceeding, apt to touch the point of national honor, as well as to affect the interests of individuals."). See generally HENRY WHEATON, ENQUIRY INTO THE VALIDITY OF THE BRITISH CLAIM TO A RIGHT OF VISITATION AND SEARCH OF American Vessels Suspected to Be Engaged in the African Slave-Trade 148-51 (Philadelphia, Lea \& Blanchard 1842) (arguing strongly against the British right of search on international law and policy grounds, while surveying the history of the negotiations regarding the suppression of the slave trade, including the mixedcommissions episode). 
after 1825, even if still desired by Britain. Nonetheless, the commissions hovered in the background of the subsequent search debates. ${ }^{161}$

\section{UNDERSTANDING THE CONSTITUTIONAL OBJECTIONS}

The rejection of mixed courts on constitutional grounds may seem surprising, as the United States had agreed to other "mixed commissions" under the Jay Treaty. Moreover, Congress had established non-Article III courts for the Louisiana and Mississippi territories. $^{162}$ Indeed, just a few hours after rejecting the slave-trade mixed commissions, the Cabinet discussed, without any constitutional hesitation, the possibility of a mixed commission to adjudicate claims of U.S. citizens against Spain. ${ }^{163}$ The Cabinet was either shamelessly hypocritical, or it saw some substantial difference between the slavetrade mixed commission and the other courts and international commissions with which the country had experience. ${ }^{164}$

This Part pieces together and evaluates the various constitutional objections advanced against the slave-trade courts. These arguments developed over time, and Wirt and Adams disagreed as to the reasons for the unconstitutionality. The arguments were of two kinds, structural and rights-based. Section A explains Wirt's and Adams's differing views on the nature of the Article III problem. This Section dwells more on Adams's narrower position both because it dominated the diplomatic correspondence with Britain and because it is more consis-

${ }^{161}$ See 33 SEN. J. app. 689, 693 (1842) (message of President John Tyler) (mentioning treaties between Britain and other nations that authorized each to "seize, and bring in for adjudication, vessels found engaged in the slave-trade" as part of the background to U.S. efforts to refrain from any such commitments). When the rejection of the commissions was recalled, it was treated as a settled question. Cf. United States v. Watkins, 28 F. Cas. 419, 462 (C.C.D.C. 1829) (No. 16,649) (Thruston, J., dissenting) ("The negotiation with Great Britain, respecting the suppression of the slave trade, failed upon the ground that the United States could not give power to the courts of another nation to punish the violation of the laws of the United States.").

${ }^{162}$ Ironically, John Quincy Adams had been one of the few to argue that the arrangement for territorial judges was unconstitutional. See DAVID P. CURRIE, THE CONSTITUTION IN CONGRESS: THE JEFFERSONIANS, 1801-1829, at 113 n.195 (2001).

${ }^{163}$ See Diary Entry of John Quincy Adams, supra note 104, at 152. The idea was raised as part of the Adams-Onis Treaty, which granted Florida to America. The Cabinet ultimately favored all-American commissioners, though apparently not for constitutional reasons. The constitutionality of the commission's judicial role was upheld in Comegys v. Vasse, 26 U.S. (1 Pet.) 193 (1828). See id. at 212-13 ("The object of the treaty was to invest the commissioners with full power and authority to ... decide upon the amount and validity of the asserted claims upon Spain, for damages and injuries.... $[\mathrm{T}]$ he award of the commissioners ... presents no bar to the action .....").

${ }^{164}$ Adams in his diaries does not suggest hypocrisy. 
tent with both past and future practice. Section B discusses a second wave of objections raised by Adams, which focus on the mixed courts' failure to afford American defendants such Bill of Rights protections as the jury trial.

While Adams's rights-based views resonate with modern jurisprudence, they still invite the question of how Adams and his colleagues reconciled these views with their role in creating the very tribunals that modern scholars take as a permissive precedent for the entire concept of non-Article III courts. These tribunals-like the Jay Treaty commission and the early territorial courts-seem to have had some of the same defects that the Monroe Administration complained of in the slave-trade courts. Section $\mathrm{C}$ seeks to isolate the key differences between the slave-trade courts and other tribunals in order to understand why the former were considered unconstitutional. It suggests that the criminal jurisdiction of the slave-trade courts made nineteenthcentury statesmen decide to treat them differently from other bodies. Finally, Section D explains why these arguments deserve considerable respect despite their having been formulated by the political branches.

\section{A. Structural Constitutional Objections}

\section{Wirt's Nondelegation Arguments}

At the Cabinet meeting in 1818 where the mixed-commission proposal was first aired, Wirt rattled off a list of constitutional objections of varying degrees of plausibility. ${ }^{165}$ His blunderbuss attack can be broken down into four separate objections: nondelegation, nationality of the judges, extraterritorial courts, and impeachability. ${ }^{166}$ First, the judicial power is vested in Article III courts and thus cannot be given to other kinds of tribunals. This general nondelegation argument is Wirt's weightiest and the only one echoed by current critics of the international courts. Second, Wirt said that judicial power can only be given to U.S. citizens. This argument is hard to support because Article III, unlike provisions dealing with Congress and the Presidency, does not establish any nationality requirement for judges. ${ }^{167}$ Third, Wirt saw problems in a court that would "sit without the bounds

${ }^{165}$ This is at least the impression given by the condensed record of the meeting in Adams's diaries.

${ }^{166}$ See Diary Entry of John Quincy Adams, supra note 104, at 151.

167 See U.S. CONST. art. I, $\$ 2$, cl. 2 (requiring citizenship for election to the U.S. House of Representatives); id. $\S 3$, cl. 3 (requiring the same for the U.S. Senate); $i d$. art. II, $\S 1$, cl. 5 (requiring natural-born citizenship for the presidency). 
of the United States."168 Because jurisdiction was strictly territorial, based on sovereign control of an area, it was a non sequitur for a court to sit where it had no control. Still, this would not necessarily explain why a U.S. official could not exercise power abroad with the consent of the forum state. ${ }^{169}$ Finally, Wirt noted that unlike Article III judges, the commissioners would not be "amenable to impeachment." judges would not have life tenure was not mentioned as a concern. Thus, Wirt's concern was that the judges would be insufficiently accountable rather than insufficiently independent. Their exercise of power over U.S. citizens would be unhampered by any domestic control.

Adams replied that there was no nondelegation problem. The source of Congress's authority to establish such a court, he replied, was not Article III but rather the treaty power, which was "without limitation in the Constitution." ${ }^{171} \mathrm{He}$ cited as precedent the prior international commissions to which the United States had agreed. ${ }^{172}$ While the vote

${ }^{168}$ See Diary Entry of John Quincy Adams, supra note 104, at 151.

${ }^{169}$ Adams made this point by recalling the "Courts of Admiralty which it has been proposed to establish at Naples if we could have obtained consent of that Government." Id.

${ }^{170} \mathrm{Id}$. Wirt was probably referring to the foreign commissioners, not the American ones; the latter could probably have been removed by Congress like other appointed officials under the general impeachment provision. See U.S. CONST. art. II, § 4 (providing that "all civil officers of the United States" can be removed for certain kinds of wrongdoing); see also CURRIE, supra note 162, at 113 n.192 (noting that Congress assumed that territorial officers and judges could be impeached). Their impeachability would depend on their being U.S. officials seconded to a foreign agency rather than on their being officers of a non-U.S. institution who happened to have been selected by Washington. Some might argue that nonimpeachability would demonstrate that the official was not an officer of the United States and thus eliminate any separation of powers concerns. Yet this tack would make international delegations constitutionally even easier than domestic ones.

In regard to the slave court, the assumption seems to have been that U.S. commissioners remained removable officers of the United States. A modern case involving the U.S.-Canada Boundary Commission opined in dicta that treaties could not limit presidential removal power to the same extent statutes could. See Leu v. Int'l Boundary Comm'n, 523 F. Supp. 2d 1199, 1207-08, 1211-12 (W.D. Wash. 2007) (holding that while the International Boundary Commission was supposed to function as an independent agency, its constitutive treaty did not limit presidential removal power over the U.S. commissioner). It would be much harder to say that treaties could insulate an official from impeachment or removal in ways that would, in a domestic setting, violate the separation of powers.

${ }^{171}$ Diary Entry of John Quincy Adams, supra note 104, at 151. Adams appears to have anticipated the view, associated with Missouri $v$. Holland, that Congress can, pursuant to a valid treaty, do what would otherwise exceed its enumerated powers.

${ }^{172}$ Two years later, the British ambassador futilely invoked the Jay Treaty precedent to Adams, who by then was set on the proposal's unconstitutionality. See Diary Entry of John Quincy Adams (Oct. 20, 1820), supra note 113, at 190 (recounting 
against the proposal was unanimous, Adams, in his diary, suggested that at the end of the Cabinet meeting he remained unconvinced by Wirt's positions. At some point, however, he concluded that the tribunals would be unconstitutional for an entirely different set of reasons.

\section{Adams's Appellate Objections}

Despite his rejection of Wirt's nondelegation arguments, Adams came to the conclusion that mixed commissions would nonetheless be impermissible on other grounds. His change of position can be inferred not only from his vigorous insistence in discussions with Canning that the commissions were unconstitutional-for this may merely mean he was a faithful agent not deviating from the Administration's position ${ }^{173}$-but also from the fact that he raised, and insisted on, constitutional objections to the courts in the subsequent diplomatic correspondence. Adams cited the lack of review by Article III courts and the lack of individual rights protections as new reasons that the commissions were unconstitutional, ${ }^{174}$ which he substituted for the nondelegation objection. Even his diaries-where he sometimes recorded sentiments at odds with those expressed in his diplomatic correspondence-show him to be committed to the position he took publicly against the constitutionality of the mixed commissions. ${ }^{175}$

In his correspondence with London, Adams argued that the lack of appeal from the mixed commissions' judgments was a constitutional problem. Congress could not create tribunals "irresponsible to the

Canning's plea to the "precedent [of] the Commissions to which we had agreed by Treaty to submit questions of property and territorial rights").

${ }^{173}$ If Adams disagreed with the Monroe Administration's position on the mixed courts, he could in theory have reversed it when he succeeded as President. In practice, this would not have been a likely course, and his failure to revive the question as President means little. Adams was not enthusiastic about the right of search in the first place, the Senate was hostile to it, and Adams's close election by the House of Representatives left him with little political capital. There would have been little reason to revisit the unpopular issue. Moreover, the Senate's rejection of the modified search treaty in 1824 cast a pall on subsequent negotiations during Adams's Administration. See Letter from John Quincy Adams to Albert Gallatin (Dec. 12, 1827) (writing that Canning "had been laying up a stock of resentments, for which he was hoping to expose us to public and open humiliation" because of the "disappointment of the slavetrade convention"), in THE WRITINGS OF ALBERT GALLATIN, supra note 123, at 398.

${ }^{174}$ Adams's positions would later be fully endorsed by the Cabinet. See Diary Entry of John Quincy Adams (Dec. 23, 1820), supra note 119, at 217.

${ }^{175}$ See Diary Entry of John Quincy Adams (Oct. 26, 1820), supra note 123, at 192 ("I had told [Canning] there was one certain Constitutional difficulty which we saw no way of getting over. This of itself was decisive for the present. I had not thought it necessary to mention that there was another, which might prove no less embarrassing."). 
supreme corrective tribunal of the American Union."176 The mixed court's decisions could not be reviewed by the Supreme Court or any tribunal. ${ }^{177}$ (Indeed, there was no appeals process at all under the mixed-courts treaties.)

Article I gives Congress the power to "constitute Tribunals inferior to the supreme Court,"178 while Article III says that the "judicial Power of the United States, shall be vested in one supreme Court, and in such inferior Courts as the Congress may from time to time ordain and establish." ${ }^{179}$ The former provision suggests to some that there is an entity called a "tribunal," distinct from a court, that Congress can create pursuant to this Article I "constituting" power-thus called an "Article I court." The text of Clause 9 suggests that tribunals as well as courts must be "inferior" to the Supreme Court. Indeed, one might think the very identification of the only judicial body created by the Constitution as "supreme" means it must have precedence over all other federally created tribunals. ${ }^{180}$ As a result, Adams's argument that nonreviewability made the mixed courts unconstitutional has a firmer textual basis than do the general structural nondelegation arguments. ${ }^{181}$

The appellate objection resonates with the modern jurisprudence on non-Article III tribunals. In the modern view, non-Article III tribunals must be reviewable by Article III courts at least to some extent. ${ }^{182}$ Complete preclusion of Supreme Court review of questions of federal law, especially constitutional ones, is seen as a highly dubious

${ }^{176}$ WHEATON, supra note 160 , at 79.

${ }^{177}$ See 42 ANNALS OF CONG. app. at 3011 (1823) (letter from John Quincy Adams to Stratford Canning) (objecting that the commissions would be "under no subordination to the ordinary judicial tribunals of the country"); Letter from John Quincy Adams to Albert Gallatin and Richard Rush, supra note 109, at 73 (noting that the tribunal would be unacceptable because it would "decid[e] upon the statutes of the United States without appeal"). This point may have been made in the Cabinet debate but was not recorded by Adams in his diary.

${ }^{178}$ U.S. CONST. art. I, § 8, cl. 9.

${ }^{179} I d$. art. III, $\S 1$.

${ }^{180}$ It is not clear what it means for a court to be "inferior." Professor James Pfander has argued powerfully that it means there must be the possibility of direct or habeas review. See James E. Pfander, Essay, Federal Supremacy, State Court Inferiority, and the Constitutionality of Jurisdiction-Stripping Legislation, 101 NW. U. L. REV. 191, 212-14 (2007). One might instead argue that inferiority means the Supreme Court's precedents are binding rather than persuasive authority for all lower courts. See id. at 214. The mixed commissions were not inferior in either of these senses.

${ }^{181}$ Indeed, Adams might have elaborated on his argument by noting that writs of habeas corpus would presumably not run to the slave-trade courts; this would eliminate any avenue for Supreme Court review and possibly constitute a suspension of the writ.

${ }^{182}$ See supra subsection I.A.3. 
use of the Article III "exceptions" power. Finally, non-appealability distinguishes the proposed commissions from territorial courts, though not from earlier international commissions or courts martial.

\section{B. Bill of Rights Objections}

A separate set of objections stressed that the mixed courts would not be subject to the Bill of Rights. The treaty would create a court in which United States citizens could be tried for conduct that was criminal under American law without the relevant constitutional protections of individual rights. In the view of Adams and others, this was outside the Senate's power.

The lack of grand and petit juries was the principal defect. Adams argued that the Constitution "expressly prohibit[ed] ... erecting any judicial courts ... to which American citizens should be called to answer for any penal offence without the intervention of a grand jury to accuse and of a jury of trial to decide upon the charge." U.S. government cannot create a system to try and to punish citizens that escapes the procedural requirements of the Fifth and Sixth Amendments. ${ }^{184}$ Indeed, in one interview with Canning, who had come to rehash the matter in hopes of finding a solution compatible with U.S. law, ${ }^{185}$ Adams dramatically read the Fifth Amendment aloud, concluding that it "amount[ed] to an express prohibition" on creating such a tribunal. ${ }^{186}$

The severity of the crimes and their potential consequences reinforced the need for a jury. ${ }^{187}$ Federal juries in slave-trade trials had

${ }^{183}$ Letter from John Quincy Adams to Stratford Canning, supra note 116.

${ }^{184}$ See U.S. CONST. amend. V ("No person shall be held to answer for a capital, or otherwise infamous crime, unless on a presentment or indictment of a Grand Jury, [except in the wartime armed forces] ...."); id. amend. VI ("In all criminal prosecutions, the accused shall enjoy the right to a ... trial, by an impartial jury ...." (emphasis added)). Significantly, applicability of these amendments is not limited to any particular federal tribunal but depends instead on the defendant being held and prosecuted by the government.

${ }^{185}$ See Diary Entry of John Quincy Adams (Oct. 26, 1820) ("Mr. Canning called. ... He brought with him a long written paper, containing what he had understood as the substance of our former conversations [on the slave trade], which he ... wished to read to me ...."), supra note 113, at 191-92.

${ }^{186} I d$. at 192. Adams did not make clear if he was referring to the requirement of a grand jury or to the broader "due process" provision. However, his reference to an "express" prohibition suggests the former.

${ }^{187}$ See, e.g., 42 ANNALS OF CONG. app. at 3029 (1823) (“[W] hen the crime and the punishment are aggravated to involve the life of the accused, it affords but a more imperative inducement for securing to him the benefit of a trial by his countrymen and 
sometimes shown extreme leniency bordering on nullification. This was particularly true for minor participants, as the entire crew from cabin boy to captain faced the death penalty. ${ }^{188}$ The perceived inadequacy of U.S. justice was one of the reasons Britain sought to establish international courts in the first place. Adams seemed to think that the jury-trial right was not merely a guarantee of fairness but of judgment by people with certain backgrounds, norms, and values. Even the fairest foreign judge could not replace a jury.

Recall that Adams had rejected the nondelegation argument against mixed courts. He reasoned that the treaty power allowed Congress to do what was not independently authorized by Article I, Section 8. Thus, it could create courts of a kind not otherwise authorized. But this did not mean those courts could be free of all constitutional constraints. Adams clearly thought that the Fifth and Sixth Amendments-and thus, presumably, the Bill of Rights-limited all exercises of the treaty power. While the treaty power could trump federalism limitations on Congress, it could not defeat enumerated individual rights (or, as his insistence on Supreme Court review demonstrated, the horizontal restraints of separation of powers).

Adams's position anticipated the approach that modern jurisprudence has taken on the limits of the treaty power. Yet the insistence that the Bill of Rights guarantees must still apply entirely anticipated Reid v. Covert, which held that treaties cannot suspend constitutional criminal process rights. ${ }^{189}$

While Missouri $v$. Holland stands for nothing more than the inapplicability of federalism and enumerated-powers limits to legislation

his peers."). The slave trade had been made a capital offense in the United States in 1820, though no other nation had attached such severe penalties to this crime. See

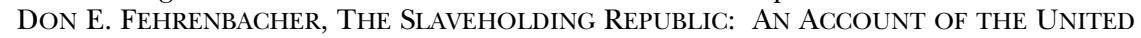
StATES GOVERnMENT'S RELATIONS TO SlAVERY 151-52 (Ward M. McAfee ed., 2001). The U.S. law was particularly severe because it applied to all crew members and owners, regardless of the extent of their role in the slave-trading expedition.

${ }^{188}$ Slave vessels were often captured on their outward voyage, when they did not yet have slaves on board. Convictions in such cases were based on circumstantial evidence involving the equipment on board. Juries, especially in Southern states, were often reluctant to convict in such cases. See Diary Entry of John Quincy Adams (May 8, 1840) ("I suppose it as impossible to commit a slave-trader at Baltimore as in the island of Cuba ...."), in 10 MEMOIRS OF JOHN QUINCY ADAMS 283, 284 (Charles Francis Adams ed., Philadelphia, J.B. Lippincott \& Co. 1876). This reluctance was greatly reinforced by the severe punishment under the 1820 Act of Congress. See FEHRENBACHER, supra note 187, at 152, 199-200 (explaining that although the Act imposed the death penalty for slave trading, only one person was ever executed under the Act, and not until 1862).

${ }^{189}$ See supra note 68 and accompanying text. 
pursuant to treaties, it is sometimes more broadly described as exempting treaty legislation from any "structural" constitutional rules. ${ }^{190}$ Adams's objections to the slave-trade courts reveal the difficulty in treating structural limitations differently than rights-based ones. ${ }^{191}$ Consider the right to a jury trial. Here, the Bill of Rights and Article III overlap: both provide for a jury trial in criminal cases. ${ }^{192}$ The location of the criminal jury right in Article III may suggest a greater constitutional imperative for Article III courts in criminal than in civil cases. $^{193}$ Moreover, Article III may be a package deal: the requirement of Article III juries in criminal cases may presume an Article III judge to charge them. ${ }^{194}$ Seventh Amendment juries, by contrast, may be able to operate under the guidance of non-Article III judges. ${ }^{195}$ If treaties cannot abolish individual rights, they also cannot fully get around Article III, since the Article includes some such rights. This view may have informed the Article III objections against the mixed tribunals. ${ }^{196}$

${ }^{190}$ See McGinnis, supra note 4, at 1746 (“[T] he treaty power dissolves structural constitutional impediments to international delegation ....”).

191 See Antonin Scalia, Foreword: The Importance of Structure in Constitutional Interpretation, 83 NOTRE DAME L. REv. 1417, 1418 (2008) (arguing that the structural provisions of the Constitution were designed to protect individual liberty).

${ }^{192}$ Compare U.S. CONST. art. III, § 2, cl. 3 ("The Trial of all Crimes, except in Cases of Impeachment, shall be by Jury ...."), with id. amend. VI ("In all criminal prosecutions, the accused shall enjoy the right to a ... trial, by an impartial jury ....").

${ }^{193}$ This view comports with current jurisprudence on non-Article III courts, which allows them to the extent they are not an end run around the civil jury-trial right. See, e.g., Granfinanciera, S.A. v. Nordberg, 492 U.S. 33, 61-65 (1989) (noting that nonArticle III courts may be allowed but that the Seventh Amendment right to a jury trial may not be eliminated "merely by relabeling the cause of action to which it attaches and placing exclusive jurisdiction" in a non-Article III court).

${ }^{194}$ See id. at 62-63 ("[The] claim that juries may serve usefully as checks only on the decisions of judges who enjoy life tenure overlooks the extent to which judges who are appointed for fixed terms may be beholden to Congress or Executive Officials, and thus ignores the potential for juries to exercise beneficial restraint on their decisions." (citation omitted)).

${ }^{195}$ This is the practice in bankruptcy courts, though it requires the parties' consent. See 28 U.S.C. $\$ 157$ (e) (2006) ("If the right to a jury trial applies in a proceeding that may be heard under this section by a bankruptcy judge, the bankruptcy judge may conduct the jury trial if specially designated to exercise such jurisdiction by the district court and with the express consent of all the parties.").

${ }^{196}$ This may help explain why the mixed tribunals were objectionable but the use of mixed commissions to settle civil claims between nationals of the United States and other countries was not. 


\section{The Importance of Criminal Jurisdiction}

The extent of the proposed mixed courts' jurisdiction may be crucial to understanding the constitutional controversy. The matter is somewhat obscure because the British did not spell out the details of their proposal. (To avoid chiseling by the Americans, Canning did not want to commit a draft to writing until the parties reached an agreement in principle.) However, much of the discussion in Washington treated the courts as if they would exercise criminal jurisdiction over the officers and crew of the vessel. ${ }^{197}$ As a diplomatic note to the British put it, the United States could not give a foreign court "power over the persons, property and reputation of the citizens." Adams always referred to the commissions as "penal" and described them as "trying" U.S. citizens. ${ }^{199}$ Gallatin thus explained America's refusal to join the British project on the ground that it would be "repugnant to our Constitution" for the "property and, above all, the persons of our citizens" to be tried by a mixed commission. ${ }^{200}$ As late as 1823, Adams described the proposal as one where an "offence" would be "charged upon [our] citizens." ${ }^{201}$ Moreover, the repeated objection that the tribunals would not employ grand or petit juries ${ }^{202}$ suggests

${ }^{197}$ Adams spoke of the proposal as giving Britain power over "offenders and offence[s]" aboard U.S. vessels, and of the mixed commission having "power over the persons ... and reputation of the citizens of this country." Letter from John Quincy Adams to Stratford Canning, supra note 116. When the House committee wrote in support of the ultimately failed search treaty, it noted that this arrangement represented a modification of the original British proposal in that it "contemplate[d] the trial and condemnation of such American citizens as may be found engaged in this forbidden trade, not by mixed tribunals sitting in a foreign country, but by existing courts, of competent jurisdiction, in the United States." COMM. ON THE SUPPRESSION OF THE SLAVE TRADE, supra note 149, at 3. Similarly, the French, who also rejected the British proposals, clearly understood that they only contemplated jurisdiction over the vessel yet referred to them as "mixed commissions, charged with pronouncing upon the culpability of the individuals." Memoir of the French Government on the Slave Trade, in COMM. ON THE SuPPRESSION OF THE SLAVE TRADE, supra note 149, at 74, 79.

${ }^{198}$ Letter from John Quincy Adams to Stratford Canning, supra note 116.

${ }^{199} I d$.

${ }^{200}$ Letter from Albert Gallatin to John Quincy Adams (Feb. 2, 1822), in THE WRITINGS OF ALBERT GALLATIN, supra note 123, at 229, 230 (emphasis added).

20142 ANNALS OF CONG. app. at 3029 (1823) (letter from John Quincy Adams to Alexander Everett).

${ }^{202}$ Proceedings to condemn a vessel would fall within admiralty jurisdiction and be heard solely by a judge, even in United States courts. However, criminal offenses falling within the federal admiralty jurisdiction would be heard by a jury. See Granfinanciera, S.A. v. Nordberg, 492 U.S. 33, 55 n.10 (1989) ("Civil causes of action in admiralty ... are not suits at common law for Seventh Amendment purposes, and thus 
that the proposal was regarded as punitive in nature. Britain did little to dispel this impression. ${ }^{203}$ Thus, while apparently aware of the limited jurisdiction of the existing mixed commissions, the Administration also seemed to think of them as criminal. ${ }^{204}$

There are several ways to understand why the tribunals would be seen as criminal in nature. First, the British may have failed to make clear the noncriminal nature of the proposal, either by informally suggesting the possibility of criminal jurisdiction-including punishment of offenders-or simply by sending mixed signals. It could not have helped that some of the materials that the British presented to Washington also described the arrangements in criminal terms. ${ }^{205}$ The imprecision in the British proposal may have led the Administration to assume the worst. ${ }^{206}$

Castlereagh sent to Washington the mixed-court treaties with other countries as a model of his proposal. Those courts had jurisdiction only over the ships and their cargo; the crew would either be let loose or repatriated for prosecution. ${ }^{207}$ Even if, as is likely, the Administration and Congress understood that the courts would only be "authorized to con-

no constitutional right to a jury trial attaches."); Parsons v. Bedford, 28 U.S. (3 Pet.) 433, 447 (1830).

${ }^{203}$ Though Canning at one point defended the commission as akin to "trials for forfeitures," see Diary Entry of John Quincy Adams (Oct. 20, 1820), supra note 105, at 190 , he did not reiterate this argument in his numerous discussions and correspondences with Adams and Rush.

${ }^{204}$ Wheaton, writing twenty years later, when any confusion about the nature of the proposal was surely resolved, also presented it in a criminal light. See WhEATon, supra note 160.

${ }^{205}$ An 1819 resolution of the House of Lords, calling for the United States to join the mixed-courts system, noted that it would allow for "seizing vessels engaged in the criminal traffic, and for bringing to punishment those who shall still be guilty of these nefarious practices." Resolution of July 9, 1819, reprinted in AMERICAN STATE PAPERS, supra note 109, at 80 . Similarly, a counterproposal by Russia called for establishing, instead of the mixed-tribunals network, an international court that would "judge all crimes relating to the trade." Opinion of the Russian Cabinet upon the Slave Trade (Nov. 7, 1818), in COMM. ON THE SUPPRESSION OF THE SLAVE TRADE, supra note 149, at 72, 73-74. The offer appears to be a tactic to refuse Britain's offer by agreeing to even more than London could accept.

${ }^{206}$ Similarly, uncertainties about the jurisdiction of the International Criminal Court lead those inclined to be suspicious to entertain the worst-case scenarios, which supporters of the court dismiss as unlikely.

${ }^{207}$ See Despatch from Lord Castlereagh to Earl Bathurst (Nov. 2, 1818) (Memorandum A) ("The mixed commission has no jurisdiction of a criminal character ...."), in AMERICAN STATE PAPERS, supra note 109, at 115; see also Martinez, supra note 15, at 591 (noting that mixed courts lacked criminal jurisdiction over the crew of a seized slave vessel). 
demn" vessels, they still may have seen this as criminal. ${ }^{208}$ The proceedings which Castlereagh described as noncriminal would have been regarded as criminal under U.S. law. ${ }^{209}$ Condemnation of a vessel, while nominally in rem, can be criminal when done to punish the owner. ${ }^{210}$ The slave-court condemnation would have the key characteristic of a criminal proceeding in that it determined the blameworthiness of the owners and crew. ${ }^{211}$ In such cases, forfeiture proceedings would trigger constitutional criminal procedure protections. ${ }^{212}$ Whether forfeiture was criminal appears to have been a highly fact-specific question in the early nineteenth century. While not necessarily criminal, ${ }^{213}$ it could be consi-

${ }^{208}$ Diary Entry of John Quincy Adams, supra note 104, at 151; see also Rome Statute of the International Criminal Court art. 77 (2) (b), July 17, 1998, 2187 U.N.T.S. 90 (providing for forfeiture of property as a criminal penalty administrable by the ICC); $37 \mathrm{AN}$ NALS OF CONG. 1067 (1821) (describing the proposal as giving courts jurisdiction over vessels only).

${ }^{209}$ Ironically, confiscation of assets-whether civil or criminal-was later cited by Crowell $v$. Benson, the seminal modern case on the permissibility of non-Article III adjudication, as a paradigmatic example of the kind of case that required an Article III forum even at the trial level. See Crowell v. Benson, 285 U.S. 22, 60 (1932).

${ }^{210}$ See The Emily and the Caroline, 22 U.S. (9 Wheat.) 381, 388-89 (1824) ("[The U.S. statute allowing for condemnation of vessels fitted out for the slave trade] furnishes authority to take from the offender the means designed for the perpetration of the mischief. This is not punishing, criminally, the intention merely; it is the preparation of the vessel, and the purpose for which she is to be employed, that constitute the offence ...." (emphasis added)). Justice Thompson had, until the previous year, been the Navy Secretary in Monroe's Administration and had participated in all the Cabinet discussions of the mixed-courts treaty. Thus, The Emily is particularly strong evidence that the Cabinet saw the British proposals as "punishing criminally." This was certainly the view of the French. See Memoir of the French Government on the Slave Trade, supra note 197 ("In vain would it be alleged that the mixed commission does not exercise its jurisdiction in a criminal manner, and that it only pronounces upon the legality of the seizure of the vessel ...." (internal quotation marks omitted)).

${ }^{211}$ See Letter from John Quincy Adams to Stratford Canning, supra note 116 (noting that commissions would have power over the "reputation" of U.S. citizens).

${ }^{212}$ See Boyd v. United States, 116 U.S. 616, 633-34 (1886) (opining that "proceedings instituted for the purpose of declaring the forfeiture of a man's property by reason of offences committed by him, though they may be civil in form, are in their nature criminal" and thus trigger Bill of Rights protections); see also One 1958 Plymouth Sedan v. Pennsylvania, 380 U.S. 693, 696 (1965) (holding that evidence obtained in violation of the Fourth Amendment is admissible and may not be relied on to sustain a forfeiture). But see United States v. Ursery, 518 U.S. 267, 270-71 (1996) (holding that civil forfeiture is not a "punishment" for double jeopardy purposes). See generally The Palmyra, 25 U.S. (12 Wheat.) 1, 14-15 (1827) (discussing the relation between forfeiture in admiralty and criminal liability, and holding that the latter is not necessary for the former).

${ }^{213}$ See The Three Friends, 166 U.S. 1, 49-50 (1897) ("The suit is a civil suit in rem for the condemnation of the vessel [for violations of neutrality] only, and is not a criminal prosecution. The two proceedings are wholly independent and pursued in different courts, and the result in each might be different."). 
dered so when it was punitive in purpose or part of a scheme of criminal enforcement. $^{214}$

Forfeiture was clearly criminal in slave-trading cases. The condemnation of a vessel in U.S. courts would fall under the Act criminalizing the slave trade. In these cases, proving criminal intent on the part of the owners or crew was essential to condemning a vessel. ${ }^{215}$ Several other factors suggest the criminal nature of the forfeiture: First, its purpose was to punish the vessel's owners and backers; losing a ship was regarded as an extremely severe sanction. ${ }^{216}$ Second, in form, it was not a dispute between private parties, or even an action to enforce what are now called "public rights." 217 Rather, the proceeding was a prosecution by a sovereign authority against private individuals' preexisting common law property rights. Deprivation of property can be a criminal punishment as surely as deprivation of life or liberty. ${ }^{218}$

Finally, there may have been apprehension that the tribunal's judgments would have a preclusive effect in subsequent criminal proceedings in U.S. courts. ${ }^{219}$ If a vessel were judged to be engaged in the slave trade, there were no other elements needed to find the officers and crew guilty of slave trading. Slave traders were simply those operating vessels engaged in the slave trade. Concerns about the preclusive effect of the mixed courts were prominently voiced by the French in explaining their refusal to join the treaty system:

To pronounce upon the legality of the seizure is to judge the question as much as it is possible to do it .... His fate is thenceforward fixed.

${ }^{214}$ See United States v. Eighty-Four Boxes of Sugar, 32 U.S. (7 Pet.) 453, 462-63 (1833) (requiring more than "accident or mistake" for civil forfeiture because the forfeiture statute was considered "a highly penal law"); The Marianna Flora, 24 U.S. (11 Wheat.) 1, 39-40 (1826) (stating that confiscation of a vessel may be proper punishment for "gross violations of the law of nations on the high seas" but not for "lighter faults, or common negligence").

${ }_{215}$ See, e.g., Strohm v. United States, 23 F. Cas. 240, 241 (C.C.D. Md. 1840) (No. $13,539)$.

${ }^{216}$ See The Marianna Flora, 24 U.S. at 40 (describing forfeiture of a vessel that attacked a U.S. Navy ship in mistaken self-defense as "such harsh punishment[]" because, unlike damages, the relief was not proportionate to the harm caused).

${ }^{217}$ See supra text accompanying notes 43-48.

${ }^{218}$ See United States v. Mann, 26 F. Cas. 1153, 1154 (C.C.D.N.H. 1812) (No. 15,718 ) (recognizing that fines and forfeitures could be either civil or criminal, depending on the language and context of the statute).

${ }^{219}$ See 42 ANNALS OF CONG. app. at 3029 (1823) (suggesting that mixed tribunals would leave defendants open to capital punishment, which was available in the United States upon conviction of slave trading but was not a punishment that the mixed court itself could impose). 
It matters little that the penalties which he has or has not incurred be determined by the code of his country, or by that of another. When he has undergone the examination of the commission, it only remains to apply this code, or to set him at liberty; he is then in reality judged, and that not by his natural judges. ${ }^{220}$

While preclusion in a criminal case seems far-fetched, concerns may have been based on the idea that judgments of international tribunals to which the United States was a party were final and binding on U.S. courts, even in criminal cases. ${ }^{221}$ Moreover, the proposed treaty may well have required by its terms that judgments of the courtalthough made under a "guilty until proven innocent" standard ${ }^{222}-$ would have effect in a subsequent domestic prosecution. ${ }^{223}$

\section{The Precedential Value of the Rejection}

Having surveyed the legal arguments against joining the slavetrade courts in the previous sections of this Part, this final Section evaluates the precedential weight that should be given to these views. Because the constitutional opinions were expressed by the political branches, one may wonder to what extent the objections to the mixed courts were motivated by politics or other extralegal considerations. This Section shows that the constitutional objections were widely held and had significant indicia of sincerity. At the same time, the speed and unanimity with which the treaty was rejected limits what one can

${ }^{220}$ Memoir of the French Government on the Slave Trade, supra note 197, at 78. While the U.S. rules of estoppel would likely differ from those of France, the memo seems to refer to a de facto, if not de jure, estoppel. In any case, the preclusive effects in a subsequent criminal case of a judgment of an international mixed court in U.S. law are entirely unclear.

221 This issue was recently forcefully argued with respect to the International Court of Justice in Medellin v. Texas, 128 S. Ct. 1346, 1360-65 (2008). While the Supreme Court rejected the view that the ICJ's decisions are automatically binding, it treated the question as one of treaty intention, to be decided on a case-by-case basis. See id. at 1356-57.

${ }^{222}$ The treaty contained "equipment articles," which allowed vessels to be seized on suspicion of involvement in the slave trade if they carried equipment typical of a slave vessel. See Treaty Between the United States and Great Britain for the Suppression of the Slave Trade, U.S.-Gr. Brit., arts. VI-IX, Apr. 7, 1862, 12 Stat. 1225. This could range from the very suspicious, such as shackles, to the potentially benign, such as an abundance of water and other routine supplies. See id. art. VI. Vessels apprehended with such equipment would be condemned unless they produced "clear and incontrovertible evidence, proving to the satisfaction of the mixed court of justice, that . . the vessel was employed in a lawful undertaking." Id.

${ }^{223}$ Under the terms of the treaty eventually signed by the United States, the crew of a condemned vessel would be presumed guilty in a subsequent domestic prosecution. See id. art. IX (authorizing sentencing by the home country of all crew members condemned before the mixed courts). 
learn from the episode. This Section, however, also shows that the precedent of the slave-trade courts cannot automatically be extended to the areas where international criminal courts are most likely to be active today-for universal-jurisdiction offenses and crimes by members of the military.

\section{Sincerity}

The objections to Britain's proposed slave-trade measures were connected to general Anglophobia and bitter feelings over Britain's ongoing practice of impressing sailors from U.S. vessels. Adams openly admitted these motives in discussions with the British. ${ }^{224}$

However, these considerations were only raised with respect to the right of search, not mixed commissions. Objections to the two were always treated as distinct. ${ }^{225}$ The openness with which the Administration stated the policy reasons for opposing mutual search ${ }^{226}$ renders it unlikely that it would conjure a constitutional ground for opposing the mixed-courts part of the proposal. Conversely, if the Administration contrived a constitutional objection to mixed commissions, it is hard to understand why it did not offer a constitutional pretext for opposing search. ${ }^{227}$ This is especially the case given that the right of search was the logically anterior issue.

${ }^{224}$ For example, Adams recounted in his diary one such discussion with Canning:

I also went largely into the objection arising from the analogy between the right of visitation and search proposed to be given by the Convention, and the claim of Great Britain to the right of visitation and search to impress men. The conversation was altogether free and unreserved, the discussion invariably temperate .... [Canning] hint[ed] some regret that we should even harbor the sentiment that there was any analogy between them, or bring that subject into view at all ... but [I] observed that it was indispensable to unfold with candor and sincerity all our objections to the proposed Convention.

Diary Entry of John Quincy Adams (Oct. 20, 1820), supra note 113, at 189-90.

${ }^{225}$ See 42 ANNALS OF CONG. app. at 3019 (1823) ("Our objection has been of two kinds; first, to the mixed commissions, as inconsistent with our Constitution; and secondly, to the right of search, as a dangerous precedent, liable to abuse, and odious to the feelings and recollections of our country.").

${ }^{226}$ See id. at 3019-20 (declaring that the American government disagreed with the right to search American vessels because of fears of unwanted encroachment and past incidents of maltreatment).

${ }^{227}$ Fabricated arguments are presumably always available. By analogy to the nondelegation argument against mixed commissions, the Administration might have said that using British cruisers to police violations of American anti-slave-trade laws would infringe on the President's power to "take Care that the Laws be faithfully executed." U.S. CONST. art. II, $\$ 3$. 
Moreover, the types of political concerns that incited opposition to the general project ${ }^{228}$ did not apply to the mixed-courts proposal, which would neither bolster British naval dominance nor carry associations of impressment. ${ }^{229}$ Thus, only a strong general Anglophobia could color officials' judgment of the mixed-commission question. Certainly, Monroe and some members of his Cabinet may have been visceral Anglophobes, ${ }^{230}$ but the same could not be said of Adams, Wirt, Thompson, Rush, Gallatin, and many members of the House.

A number of other circumstances suggest that the constitutional arguments were sincere. The private papers of Adams, Gallatin, Monroe, Rush, and others betray no ulterior motives. ${ }^{231}$ On the contrary, they discuss the constitutional issues with nothing but seriousness. Within the Cabinet, Adams was particularly hostile to any concession on the right of search. Yet when the mixed-commission issue was raised, he challenged Wirt's Article III arguments even though they would tend to defeat participation in the search project. This suggests that, at least on this issue, Adams would not have manufactured constitutional arguments to support the outcomes he desired. Another indicator of the sincerity of the constitutional objections is the price the Administration was willing to pay to maintain it. London repeatedly signaled its willingness to make substantial concessions on other important fronts in exchange for mixed courts. ${ }^{232}$

${ }^{228}$ Again, these concerns stemmed from a reluctance to concede anything that might confirm Britain's role as the police of the oceans or allow Britain to abuse the right of search to harass U.S. vessels and impress sailors.

${ }^{229}$ The commissions may also have been reminiscent of the British military and admiralty tribunals established by the British in the colonies in the decades before the Revolutionary War. These courts were one of the colonists' major grievances. See THE DECLARATION OF INDEPENDENCE paras. 20-21 (U.S. 1776) (criticizing King George III "[f]or depriving us, in many Cases, of the Benefits of Trial by Jury" and "[f]or transporting us beyond Seas to be tried for pretended Offences"); JOHN QuINCY ADAMS, The Jubilee of the Constitution: A Discourse 8-9 (New York, Samuel Colman 1839) ("Parliament ... in their omnipotence, instead of trial by jury and the Habeas Corpus, enacted admiralty courts in England to try Americans ...."). However, there is no indication that these played any role in the mixed-commission question, and it seems unlikely that they would have: five decades is a long time for political memory.

${ }^{230}$ See, e.g., REPORT ON RELATIONS WITH GREAT BRITAIN (Nov. 29, 1811) (describing Calhoun as an open Anglophobe), reprinted in 1 THE PAPERS OF JOHN C. CALHOUN 66-67 (Robert L. Meriwether ed., 1959).

${ }^{231}$ Adams noted in his diaries, for instance, when he took a position in public that he privately disagreed with. See, e.g., Diary Entry of John Quincy Adams (Nov. 17, 1821) (recalling having told Canning that the President lacked the power to extradite suspects to Britain even "though [he] was not entirely satisfied that there was a want of authority"), in 5 ADAMS MEMOIRS, supra note 104, at 400 . He did not do so here.

${ }^{232}$ See supra subsection II.C.2. 
Moreover, no one in Congress, the Administration, or the press ${ }^{233}$ suggested that mixed commissions would be constitutional. There were certainly many quarters from which objections to unsupportable constitutional arguments could have been raised. The Congresswith some Framers still in it-did not shy away from constitutional debate. For example, just a few years before the British proposed the slave-trade convention, disagreement over the scope of the treaty power led to a prolonged standoff between the House and Senate on a commercial treaty with Britain. The dispute centered on the House's role in treaties intended to have domestic affect. Bold constitutional interpretations were warmly advanced by both sides. ${ }^{234}$

While in that episode the House was fighting for its own power, doubts about the slave-trade treaty would not have been suppressed. The House did not share the Administration's bias against naval cooperation with Britain. Nonetheless, members of the House considered mixed courts an insurmountable problem. ${ }^{235}$ Nowhere was a more favorable view of the overall British enterprise taken than in the House committees. ${ }^{236}$ Yet these committees considered mixed courts a constitutional impossibility. Even the Society of Friends, which strongly supported Britain's international slave-trade campaign and bom-

${ }^{233}$ The diplomatic correspondence with Britain was covered in the press, as was the establishment of mixed courts with other countries. See, e.g., The Slave Trade-No. III, FRANKLIN GAZETTE (Phila.), Aug. 18, 1821 (describing "judicial arrangements for the execution of this project of the right of search"). The Administration's constitutional stance, however, apparently did not attract comment.

${ }^{234}$ The House argued that any treaty that would operate within Congress's enumerated powers-and certainly within those areas of legislation that must originate with the House-had to be passed by the entire legislature. The Senate claimed that all treaties, regardless of subject matter, were self-executing. See generally WiLliam RAWLe, A VIEW OF THE CONSTITUTION OF THE UNITED STATES OF AMERICA 58-70 (Philadelphia, H.C. Carey \& I. Lea 1825) (discussing the rationale behind the treaty-making requirements and noting the heated nature of the debate concerning the houses' roles); Parry, supra note 69 (discussing the debate in a broader historical context).

${ }^{235}$ Decades later, Charles Mercer, the long-serving chairman of the House slavetrade committee and one of the most ardent opponents of the trade, indulged in recriminations with Adams over responsibility for the failure of the 1824 convention. While Mercer charged the Monroe Administration with being unenthusiastic about the treaty, and perhaps hoping for its failure in the Senate, he did not cast any doubt on the validity of the objection to mixed commissions. See Charles Fenton Mercer, Address at the Anniversary of the American Colonization Society (Jan. 18, 1853), in 29 THE AFRICAN REPOSITORY 153-56 (1853).

${ }^{236}$ See 2 REg. DEB. 2257 (1826) (speech of Daniel Webster before the House of Representatives) (observing that the resolutions of the House, unlike the committee reports, did not recommend right of search and that, with the "negotiation having been concluded, in conformity to the opinions expressed, not, indeed, by the House, but by the committee, the treaty, when laid before the Senate, was rejected by that body"). 
barded Washington with petitions, does not appear to have engaged the mixed-courts issue. ${ }^{237}$

Potential critics certainly had time to respond. The original negotiations with Britain were active for a period of nine years-hardly a passing episode. Britain periodically raised the right of search again with the United States in the ensuing decades. ${ }^{238}$ Yet it never again raised the question of mixed courts, apparently understanding that issue to be off the table.

\section{Limits}

The rejection of the slave-trade court has some limitations as a usable precedent, limitations that result from the very circumstances that make the episode compelling. For one, nothing happened. Because the Administration regarded the treaty as unconstitutional, there was no opportunity for the Senate to debate the matter. Since it was posterior to the equally controversial search question, the courts received less consideration than they otherwise might have. Because the idea died stillborn, no formal public discussion of the idea occurred. Precisely because the commissions were rejected out of hand by everyone who considered the issue, there is no authoritative account of why they are unconstitutional. Rather, there is a grab bag of reasons, and it is not clear which were decisive. This weakens the episode's precedential force-much like a Supreme Court decision without a single majority opinion-but does not leave one free to ignore the unanimous outcome.

The arguments first advanced by Wirt vary greatly in their plausibility. And there is something of a moving target in Adams's repeated explanations to Canning. ${ }^{239}$ The multiplication of constitutional arguments of varying quality against the commissions may cast doubt on their seriousness. On the other hand, this could be read as an almost

${ }^{237}$ See, e.g., Diary Entry of John Quincy Adams (June 4, 1824) (recording that Quaker lobbyists expressed "their great anxiety for the suppression of the slave-trade" in negotiations), in 6 ADAMS MEMOIRS, supra note 104, at 374, 375; cf. The Slave Trade Treaty, Boston DAILY ADVERTISER, Apr. 29, 1862 (presenting with minimal comment the language of the treaty).

${ }^{238}$ During the debate over the Webster-Ashburton Treaty, the early diplomacy of the Monroe Administration was reviewed and discussed by Adams, Webster, Ingersoll, and others, with no suggestion of a change of views on the constitutional question. Adams did, however, feel compelled to admit with "bitterness" that the earlier negotiations had effectively conceded a limited right of search. CONG. GLOBE, 27th Cong., 2d Sess. 424 (1842).

${ }^{239}$ See infra note 243. 
instinctive reaction that the proposal somehow contradicted the spirit of the Constitution as well as the letter-even if one could not put a finger on precisely which letter. As Adams put it, the proposal was "adverse to the elementary principles and indispensable securities of individual rights interwoven in all the political institutions of this country." 240

\section{Universal Jurisdiction}

The proposed slave-trade courts may not answer all questions raised by modern international criminal courts because the conduct within the jurisdiction of the former was not universally cognizable at the time (piracy was the only universal offense). Many of the crimes that today's international criminal courts deal with, however, are universally cognizable. This might make a constitutional difference to the ability of Congress to participate in the creation of international courts for such crimes. ${ }^{241}$ Adams conceded that if the slave trade became a universal-jurisdiction offense under the law of nations, there would be no problem with trial before a foreign tribunal, saying " $[\mathrm{s}] \mathrm{o}$ long as the trade shall not be recognised as piracy by the law of nations, we cannot, according to our Constitution, subject our citizens to trial for being engaged in it, by any tribunal other than those of the United States." ${ }^{242}$ Because universal crimes fell within the jurisdiction of all nations, these cases would essentially be ones of extradition. ${ }^{243}$

${ }^{240}$ Letter from John Quincy Adams to Stratford Canning (Dec. 30, 1820), in AMERICAN STATE PAPERS, supra note 109, at 76.

${ }^{241}$ The universal status of a crime was thought to make a constitutional difference to the converse constitutional question: America's ability to punish crimes committed extraterritorially by foreigners. Thus, Congress did not think it could punish foreign slave trading until that offense became well accepted as a universal crime in international law. See Eugene Kontorovich, The "Define and Punish" Clause and the Limits of Universal Jurisdiction, 103 Nw. U. L. REV. 149, 195 (2009). This limitation came from the "Define and Punish" Clause of the Constitution, and it is harder to see how this could authorize the limitation of the constitutional rights of U.S. citizens. See id. at 167-68, 198-200.

${ }^{242} 42$ ANNALS OF CONG. app. at 3027-28 (1823); see also id. at 3029 (letter from John Quincy Adams to Alexander H. Everett) (arguing that because slave trading was still technically "considered as of inferior magnitude [to piracy], the Constitution of the United States forbade the submission of it, when charged upon their citizens, to any foreign tribunal").

${ }^{243}$ Adams went still further by arguing that even for universal-jurisdiction crimes, the trial must be held in the domestic courts of the offender's nation. In this view, universal jurisdiction refers simply to enforcement jurisdiction-the ability to make arrests-rather than to adjudicative jurisdiction. This is a gross misstatement of international law then and now. Considerations of comity, practicality, and national selfinterest ensured the dominance of "complementarity"-giving precedence to fora with 
Since U.S. pirates could face the alternative of a purely foreign tribunal, providing a forum with U.S. participation would be preferable even for the defendant. ${ }^{244}$ Yet if universal jurisdiction makes a constitutional difference to the extent that it allows for the reduction of individual rights, it is not a label that can simply be slapped on an offense without corresponding to an objective state of affairs in international law. ${ }^{245}$

Less weight should be given to these views than to the general constitutional opposition to international courts for the slave trade because Adams was alone in expressing the former. Unlike the broader questions, these views were not vetted by the Cabinet or approved of by Congress, though they also did not provoke any controversy. The slave trade did not become universally cognizable during the period in question, and thus the idea remained hypothetical.

\section{Offenses by Service Members}

The slave-trade-courts proposal was designed to try civilians, and thus its rejection does not, in the strictest sense, speak to the potentially distinguishable case of service members. Members of the military are subject to a distinct system of justice, which does not have juries, Article III judges, or Supreme Court review. One could argue that submitting cases involving military personnel to an international court that also lacks these features would not deprive them of any rights they currently enjoy. ${ }^{246}$

traditional jurisdictional ties. Adams was wrong that a foreign trial was not countenanced by international law. His insistence on this point betrays his aversion to British justice, and it may cast some doubt on the sincerity of his constitutional arguments. However, unlike his constitutional objections, Adams's expressed positions on universal jurisdiction were not previewed or accepted by the rest of the Administration or Congress.

${ }^{244}$ See Wedgwood, supra note 5, at 123 (outlining U.S. efforts to include standards of due process in the ICC).

245 See Eugene Kontorovich, Beyond the Article I Horizon: Congress's Enumerated Powers and Universal Jurisdiction over Drug Crimes, 93 MINN. L. REV. 1191, 1219-23 (2009) (showing that Congress's power to "define ... [p]iracies ... and offenses against the [1] aw of [n]ations," U.S. CONST. art. I, $\S 8$, cl. 10, does not allow it to invent such definitions unrestrained by objective international law).

${ }^{246}$ A similar argument prevailed in In re Ross, where the Court upheld the trial of Americans in non-Christian countries, before a U.S. consul, without any procedural protections of constitutional rights. See 140 U.S. 453, 461, 480 (1891). Had the United States not entered into treaties with foreign countries allowing for such consular courts, the American citizens would have been tried by local courts where they would have enjoyed even fewer protections. Id. at 465.

Given the focus of modern international criminal courts on crimes committed during armed conflict, this exception could be quite significant. 


\section{Foreign Territory}

U.S. merchant vessels had the legal status of U.S. territory. ${ }^{247}$ It is not clear, however, whether this factor played a role in the debate, and it was not mentioned by anyone at the time. While the extraterritorial status of ships was a well-known fact, ${ }^{248}$ its application was not straightforward. Ships were only constructively part of the territory of the countries whose flag they flew. ${ }^{249}$ It is thus not clear whether U.S. ships were regarded as equivalent to U.S. territory in the relevant constitutional senses.

Under both international law and American law, vessels were never fully treated as part of their flag state's territory in every respect. ${ }^{250}$ As early as the Robins case, fine distinctions were made between jurisdiction over vessels and the literal notion of territory. ${ }^{251}$ Whether ships count as territory for particular constitutional purposes is a separate question, the answer to which is unclear. ${ }^{252}$

${ }^{247}$ See United States v. Palmer, 16 U.S. (3 Wheat.) 610, 621 (1818) ("The jurisdiction of a nation over its public ships is exclusive every where [sic] ....").

248 But cf. In re Ross, 140 U.S. at 464 ("The deck of a private American vessel, it is true, is considered for many purposes constructively as territory of the United States, yet persons on board of such vessels, whether officers, sailors, or passengers, cannot invoke the protection of the provisions referred to until brought within the actual territorial boundaries of the United States.”). This may just mean that the Court thought habeas and other rights could not be procedurally exercised on a ship because it was outside of the jurisdiction of any district court. If the Court meant that substantive rights did not apply on board the ship, it would represent a further-and unsupportedextension of Ross's already problematic holding that the Constitution has no applicability to governmental action abroad.

${ }^{249}$ See United States v. Smiley, 27 F. Cas. 1132, 1134 (C.C.N.D. Cal. 1864) (No. 16,317) ("The constructive territory of the United States embraces vessels sailing under their flag; wherever they go they carry the laws of their country, and for a violation of them their officers and men may be subjected to punishment.").

${ }^{250}$ See, e.g., Cunard S.S. Co. v. Mellon, 262 U.S. 100, 123 (1923) ("The jurisdiction which it is intended to describe arises out of the nationality of the ship, as established by her domicile, registry and use of the flag, and partakes more of the characteristics of personal than of territorial sovereignty."); Johnson v. Twenty-One Bales, 13 F. Cas. 855, 862 (C.C.N.Y. 1814) (No. 7417) ("The notion that vessels must be considered as part of the territory of a nation, is antiquated and exploded.").

${ }^{251}$ See United States v. Robins, 27 F. Cas. 825, 838 (D.S.C. 1799) (No. 16,175) ("To suppose that Vattel mean $[\mathrm{t}]$... that the ships of a nation are, with respect to the space of water they cover on the ocean, its territory as to jurisdiction, ... as completely as its lands or rivers are, is [incorrect].”).

${ }^{252}$ See, e.g., Cunard, 262 U.S. at 121-23 (holding that despite the "metaphor" of flag-state territoriality, the Eighteenth Amendment did not apply to U.S. ships on the high seas); Lam Mow v. Nagle, 24 F.2d 316, 317-18 (9th Cir. 1928) (holding that a U.S. merchant vessel was not U.S. "territory" for purposes of the Fourteenth Amendment's birth-citizenship provision). Interestingly, in the case of the only slave trader ever ex- 
If the British sought mixed courts to punish conduct by Americans in what amounted to U.S. territory, it would strengthen the argument for unconstitutionality. Article III requires a jury trial for all "[c]rimes ... not committed within any State." 253 Presumably, this would include U.S. vessels on the high seas. Moreover, while Congress can set the "Place" for the trial, the textual location of the provision suggests that the trial would have to be before an Article III court. ${ }^{254}$ This helps explain why Article III was discussed more than the Sixth Amendment-it is the direct source of the jury-trial right here. There may also be an associated personal right to an Article III judge when the Article III jury provision is being invoked. ${ }^{255}$ In other words, crimes outside any state may be an interesting situation where concerns based on the use of non-Article III courts merge with or are subsumed by the argument for preservation of individual rights. ${ }^{256}$ The territoriality of vessels may also justify Adams and subsequent statesmen apparently treating the right to a criminal jury as more important than the right to a civil one $\mathrm{e}^{257}$-Article III's jury provision only mentions the former.

In short, while the argument against the slave-trade courts would have more force if limited to U.S. territory, it is not clear whether U.S. ships had the literal status of "islands." Thus, it is not clear if the slavetrade-court precedent was limited to cases arising within U.S. territory. Certainly Congress and the courts acted as if crimes aboard ships implicated Article III. There is also no direct evidence that U.S. officials based their arguments on this factor, though it would go far to explain some obscure points.

\section{CIVIL WAR AND CIVIL SUITS}

A surprising epilogue to the story of the slave-trade courts occurred at the height of the Civil War. The British had never flagged in their desire to conclude a slave-trade treaty. Throughout the 1850s, their efforts to search U.S. vessels upon suspicion of slave trading were strongly and successfully resisted by Washington. However, during the

ecuted by the United States, the court suggested that birth on a U.S. vessel would help determine one's status as a U.S. citizen under pre-Fourteenth Amendment principles. See United States v. Gordon, 25 F. Cas. 1364, 1365 (C.C.S.D.N.Y. 1861) (No. 15,231).

${ }^{253}$ U.S. CONST. art. III, § 2, cl.3.

254 See id.

${ }^{255}$ See supra notes 193-194 and accompanying text.

${ }^{256}$ See supra notes 195-196.

257 See, e.g., text infra accompanying note 306. 
Civil War, London again proffered a draft convention featuring a right of search and mixed courts. ${ }^{258}$ The Lincoln Administration, in a significant diplomatic reversal, accepted the searches and commissions with almost no haggling. ${ }^{259}$ Yet the Administration refused to repudiate the core constitutional principle advanced by Adams and his colleagues: the impermissibility of granting international courts with criminal jurisdiction over Americans. By stressing the limited jurisdiction of the new tribunals, the Lincoln Administration appeased the British without openly offending the Constitution.

\section{A. Quick Negotiations}

In contrast to the protracted three-way wrangling among Britain, the Administration, and Congress in the 1820s, the entire process during the Civil War took only a few months. After sounding out the American officials in 1861, the British formally renewed their proposal on February 28, 1862. This time, they sent a completed draft treaty. ${ }^{260}$ Secretary of State Seward immediately embraced the proposal, negotiating only minor changes. Lincoln signed the Lyons-Seward Treaty, ${ }^{261}$ as it became known, on April 7 of the same year. The Senate met in closed session, and no report of the treaty was made to the press until it was ratified, unanimously, ${ }^{262}$ just three weeks after signature. The treaty had spent less than three days on the floor and four in the Foreign Relations Committee. ${ }^{263}$

Much had changed politically to make the long-rejected proposal acceptable. Most importantly, the treaty was a gesture to appease London. ${ }^{264}$ British-U.S. relations were at a point of crisis unprecedented since the War of 1812. The British seemed poised to recog-

258 See A. Taylor Milne, The Lyons-Seward Treaty of 1862, 38 AM. HIST. REV. 511, $512(1933)$.

Id. at 513-14.

${ }^{260}$ See id. at 513.

261 Treaty Between the United States and Great Britain for the Suppression of the Slave Trade, Apr. 7, 1862, 12 Stat. 1225 [hereinafter Lyons-Seward Treaty].

262 See WARrEN S. HOWARD, AMERICAN SLAVERS AND THE FEDERAL LAW, 1837-1862, at 61 (1963).

263 SUMNER, supra note 158 , at 474.

264 See Milne, supra note 258, at 511 ("To conclude with Great Britain a convention of the kind she had so frequently suggested was also a means of enlisting British sympathy for the North.”). 
nize the Confederacy as an independent sovereign. ${ }^{265}$ Reacting to this development, the Union seized Southern diplomats from a British vessel. ${ }^{266}$ The British then considered an embargo on saltpeter, an essential ingredient in gunpowder, to the Union, ${ }^{267}$ for a moment bringing the nations to the brink of war in late $1861 .^{268}$ Reconciliation with Britain was of paramount importance, and a slave-trade treaty was a cheap gesture. The treaty was also seen by contemporary commentators as one of many easy moves against anything associated with the South's "peculiar institution." ${ }^{269}$ Seward wrote, with equal measures of exaggeration and self-congratulation, that had such a treaty been made earlier, there would have been no civil war. ${ }^{270}$ This was a perfect confluence of events for the passage of the Act. Indeed, its backers recognized it could not have passed at any other time. ${ }^{271}$

\section{B. The Constitutional Argument}

Despite the favorable political environment, the constitutional issues implicated by the Lyons-Seward Treaty could not be ignored. They were addressed by Senator Charles Sumner, a leading abolitionist who made the treaty's passage his personal cause, in a long speech shortly before the final vote. ${ }^{272}$ After reviewing the history of British efforts to obtain such a treaty, Sumner turned to the constitutional is-

${ }^{265}$ See James M. MCPherson, Battle Cry of Freedom: The Civil WAR Era 387 (1988) ("[T]he British government announced an action that misled Americans on both sides of the Potomac to anticipate imminent diplomatic recognition of the Confederacy.").

${ }^{266} I d$. at 389-90.

${ }^{267}$ See id. at 390 ("The [British] government clamped an embargo on all [saltpeter] shipments to the United States until the [diplomat-seizure] crisis was resolved.").

${ }^{268}$ See id. ("War seemed imminent.").

269 The New Slave-Trade Treaty, TiMES (London), May 24, 1862, at 10 ("To hold over the South the fear of abolition is the obvious policy of Washington, and this fear will be best aroused by a show of decision in dealing with all questions relating to Slavery."), as reprinted in N.Y. TIMES, June 6, 1862, at 2.

${ }^{270}$ See Diary Entry of William H. Seward (Apr. 8, 1862) ("Had such a treaty been made in 1808 , there would now have been no sedition here ...."), in 5 THE WORKS OF William H. SEWARD 52, 52 (George Baker ed., Boston, Houghton, Mifflin \& Co. 1890) [hereinafter SEWARD].

${ }^{271}$ See Letter from Lord Lyons to Lord Russell (Apr. 7, 1862) (noting Seward's statement that, "while confident of obtaining the Ratification of the Senate at this moment, he [could] []not feel so certain that he should be able to do so a month hence"), in Milne, supra note 258, at 523.

${ }^{272}$ See Milne, supra note 258, at 514 ("Charles Sumner, who piloted [the treaty] through the Senate, had brushed aside the old contention that American courts on foreign soil would be unconstitutional ...."); see also SUMNER, supra note 158, at 474 (“[O]n motion of Mr. Sumner, the Senate proceeded to consider the resolution of ratification.”). 
sues. Sumner said that in Adams's day, "the question was less understood." ${ }^{273}$ He cited Supreme Court decisions in intervening years that affirmed the constitutionality of the Territorial Courts. ${ }^{274}$ These precedents, he argued, undercut the formalistic arguments about the exclusivity of Article III and the need for impeachable judges. Just as particular Article I powers authorized territorial courts, the treaty power authorized the mixed commission. ${ }^{275}$

Next, Sumner cited the wide use of international commissions dating back to the Jay Treaty, noting that their constitutionality was unquestioned. $^{276}$ Finally, the senator appealed to practical considerations. Given the ubiquity of mixed courts in international law, the United States would be left behind and "isolated among nations" if it could not participate in such arrangements. ${ }^{277}$ The United States, the argument continued, should not be cramped in its foreign relations due to a "discarded technicality." 278

Sumner's invocation of territorial and military courts does not rebut Adams's objections. In both, habeas corpus and mandamus is available, and the President may pardon. In the territorial courts, appeals can be taken to the Supreme Court. ${ }^{279}$ The courts-martial jurisdiction only extends to members of the military or those closely associated with it. ${ }^{280}$

Sumner's argument about a superior understanding-that "the question was less understood" by Adams-is weak. The earlier decisionmakers included participants in the founding. In addition,

${ }^{273}$ Sumner, supra note 158 , at 483.

274 See id. at 483 \& n.2 (citing Am. Ins. Co. v. Canter, 26 U.S. (1 Pet.) 511, 546 (1828)). Seward also mentioned the "extra-constitutional" nature of courts martial, though he did not mention the cases that upheld them. See id. at 483 ("[C] ourts martial are also extra-constitutional, standing on the war power and the practice of nations."). In the intervening years, the Court had, however, upheld military courts martial. See Dynes v. Hoover, 61 U.S. (20 How.) 65, 82-83 (1857).

275 See Sumner, supra note 158, at 483 ("Like Territorial courts, mixed courts are plainly extra-constitutional, standing on the treaty power and the practice of nations ....”).

${ }^{276}$ See id. at 484 ("The Jay Commission was originally criticized . . . But nobody now doubts that this commission was proper.").

277 Id. at 485 .

$278 \mathrm{Id}$.

279 See Pfander, supra note 25, at 766 (stating that "federal courts have used habeas to review courts-martial, mandamus to review territorial court judgments").

${ }^{280}$ See Reid v. Covert, 354 U.S. 1, 34-35 (1957) (plurality opinion) (finding that dependents accompanying military personnel overseas were not subject to the jurisdiction of courts martial); see also Ex Parte Milligan, 71 U.S. (4 Wall.) 2, 107, 122 (1866) (finding that a trial by military commission of a U.S. civilian who "never had been in the military or naval service" was unconstitutional). 
Sumner did not point to any new development contributing to this understanding. Territorial courts had been around for over three decades when the slave courts were first proposed. Monroe, Adams, and many in Congress had been involved in their creation. While the Supreme Court had not yet upheld these courts, presumably Congress and the Administration thought they were constitutional. ${ }^{281}$ Otherwise, it is hard to imagine they would have kept creating them. Similarly, the argument from the Jay Treaty was hardly a new one.

While Sumner may not have refuted Adams's views, he may not have had to. At the very start of the speech, he noted a crucial distinction between the jurisdiction of the courts proposed forty years earlier and those created by the 1862 treaty: the constitutional objections to the former were "mitigated" because the latter gave the court jurisdiction over the vessel but not the crew. ${ }^{282}$ Sumner appears to have recognized that the crux of the earlier objections was the understanding that the court might exercise criminal jurisdiction. ${ }^{283}$ Arguably, the 1862 treaty's forfeiture provisions still amounted to criminal jurisdiction, and Sumner simply chose to characterize it differently to duck what he understood to be a constitutional difficulty.

\section{A Court with No Cases}

The constitutionality of the tribunals was never tested in court. The U.S. involvement in the trade had ceased before the judges reached their posts a year after the treaty was ratified. ${ }^{284}$ The American slave trade had been hurt by the increasingly vigorous enforce-

281 Decisions of the Court before Canter had already implied that Congress could properly give judicial functions to the territorial courts. See supra note 27 and accompanying text. Similarly, the constitutionality of courts martial was generally accepted by the early 1820s, though it had not been confirmed by the Court. As Rawle explained,

There is [a] species of courts having a special jurisdiction, from which trial by jury is also excluded, yet whose power extends to ... imprisonment, personal chastisement, and even loss of life. It will be at once perceived that we allude to courts martial.

Although not expressly mentioned in the constitution, the power to institute them is unquestionably given by the authority vested in congress to make rules for the government and regulation of the land and naval forces ....

RAWLE, supra note 234, at 209-10.

${ }^{282}$ Sumner, supra note 158, at 483 (arguing that the objections voiced by John Quincy Adams were now "wholly superficial and untenable").

${ }^{283}$ See Milne, supra note 258, at 513 (describing Seward's subterfuge in portraying the right to search as an American initiative rather than capitulation to a British request).

${ }^{284}$ See HOWARD, supra note 262, at 62-64. 
ment of British domestic laws before the start of the war ${ }^{285}$ and the blockade of Southern ports in 1861. It was becoming clear that a Union victory would end slavery altogether, thereby making slave importation financially risky. ${ }^{286}$ Finally, increased Spanish enforcement around Cuba did much of the rest of the treaty's work. ${ }^{287}$ While the treaty no doubt had some deterrent effect immediately after its ratification, it is clear that the trade would not have survived the war.

Instead of demonstrating America's amenability to having its citizens tried before international human rights courts, the mixed commissions turned out to be prototypical sinecures, hearing no cases at all. ${ }^{288}$ The first U.S. members of the international human rights tribunal collected a salary, without working, for seven years before Congress noticed. ${ }^{289}$ On March 3, 1869, the legislature requested that the President renegotiate the Lyons-Seward Treaty. The courts were terminated on June $3,1870 .^{290}$

\section{The Precedential Value of the Acceptance}

In 1862, the mixed courts were approved without hesitation. The treaty was eagerly negotiated by the Lincoln Administration and overwhelmingly adopted by the Senate. Just as the unconstitutionality of the commissions was broadly accepted in previous decades, now the opposite was the case. This may seem to cast a different light on the earlier history. Several circumstances, however, weaken the force of the Lyons-Seward Treaty as a constitutional precedent. (It should be

${ }^{285}$ See Bethell, supra note 79, at 91-92 (reviewing the success of the British navy and the British vice-admiralty courts in suppressing the slave trade in the years leading up to the war). This included the much-publicized, first-ever execution of a slave trader in February 1862. See supra note 188.

${ }^{286}$ See HOWARD, supra note 262, at 64-65.

${ }^{287}$ See id. at 65; see also Milne, supra note 258, at 516 (noting Spain's increased efforts to suppress the slave trade).

${ }^{288}$ HOWARD, supra note 262, at 62-63.

289 The salary was roughly the same as that of a congressman at the time. However, the Freetown and Cape postings were hazardous duty assignments, with death and illness rampant among the commissioners. As one senator put it, "these Courts ... have accomplished absolutely nothing for the suppression of the slave trade or any other object, as I know from a member of the Court." Fortieth Congress, Third Session, Consular Appropriations, N.Y. TiMES, Feb. 4, 1869, at 1 (quoting Sen. Patterson). Another senator noted that " $[\mathrm{t}]$ he question before the Senate was simply whether certain gentlemen should be supported out of the people's money without doing anything to earn it." Id. (quoting Sen. Hendricks).

290 See SuMNER, supra note 158, at 486 (chronicling the end of the mixed courts). 
recalled that the reversal of 1862 was not a complete one, as the limited jurisdiction over the courts was stressed. ${ }^{291}$ )

First, the treaty was an exceptional wartime measure. ${ }^{292}$ This is evident from the marked reversal made on the related issue of search. The British had still been asking for a right of search in the late 1850s. Indeed, General Lewis Cass, the Secretary of State from 1857 to 1860, resisted the British position on search perhaps more vigorously than any previous minister, and an intensive correspondence finally convinced Britain to abandon its claims to a search right. ${ }^{293}$ In 1859 , the United States announced in the strongest terms that it would never agree to search by British vessels. ${ }^{294}$ Given this massive opposition, the ease with which it was conceded in 1862 by even the most antisearch senators suggests something about the exceptional nature of the moment. ${ }^{295}$

Second, the timing and process of the treaty's ratification gives reason to doubt the quality of the constitutional deliberation. The treaty was rushed through the Senate at a time when many other pressing matters occupied its attention and when other constitutionally questionable measures proliferated. The Senate was not likely to stand on principle in a matter that could grant an immediate and vital advantage in the war. The constitutional issues were touched on briefly and incompletely. ${ }^{296}$ Sumner ignored the key arguments from the

291 See infra Section V.A.

292 See SOULSBY, supra note 12, at 174-76.

293 See 3 A Digest OF THE InTERnATIONAL LAW OF THE UNITED STATES § 327, at 142-46 (Francis Wharton ed., Washington, D.C., Gov't Printing Office 1887).

294 See id. $\$ 327$, at 145-46.

${ }^{295}$ See Letter from Horatio J. Perry to William H. Seward (July 11, 1862) (reporting that a Spanish minister was "much surprised" by reports of the treaty given that the United States had been “combatting [sic] that principle so long”), in 1 U.S. DEP'T OF State, Foreign Relations of The United States 509, 509 (Washington, D.C., Gov't Printing Office 1862).

${ }^{296}$ Strangely, although the unanimous vote on the treaty occurred in closed session, when legislation carrying the treaty into effect was before the Senate just a few months later, five senators voted against it out of "[c] onstitutional scruples." News from Washington, The Treaty for Suppressing the Slave-Trade, N.Y. TIMES, June 27, 1862, at 4. Said one senator, "I do not object to the suppression of the African slave-trade, but I do not believe that this Government has the constitutional right to establish any such court. I think the treaty ought not to have been adopted." SUMNER, supra note 158, at 486 (recording the statement of Senator Saulsbury).

It is not clear whether these senators had opposed the treaty initially; perhaps they had abstained from the vote. Cf. id. at 485 (recording Sumner's surprise at the unanimous ratification of the treaty.) The objectors were a group of mostly Northern Democrats highly critical of abolition and, in some cases, of Lincoln's policy more generally. One of them, Senator Bayard, later lost his Senate seat for refusing to take a loyalty oath that he also regarded as unconstitutional. 
1820s and based his constitutional argument largely on needing constitutional flexibility to realize vital foreign-policy goals.

The treaty may not have been contemplated to have practical effect. While it may not have been certain that the courts would hear absolutely no cases, it was foreseeable. ${ }^{297}$ Seward himself had noted in his official correspondence that the slave trade had almost completely ceased, and in March 1862 the blockade of the South was complete. ${ }^{298}$ The Confederacy had banned the slave trade in its Constitution. ${ }^{299}$ And it must have been understood that a Northern victory would make the treaty entirely moot while a Southern one would make it unenforceable. To the senators it may have been largely an expressive measure. $^{300}$

The treaty was criticized by contemporaries-including some senators. ${ }^{301}$ To be sure, most of the critics were Northern Democrats generally suspicious of the Lincoln Administration. ${ }^{302}$ But the potentially cooler post-war commentary stressed that the treaty was a wartime measure not necessarily applicable to calmer times. ${ }^{303}$ A generation

297 See A Northern Man, The Diplomatic Year: Being a Review of Mr. SeWARD's FOREIGN CORRESPONDENCE OF 1862, at 36 (2d ed., Philadelphia, John Campbell 1863) (arguing that the treaty would be "fruitless").

${ }^{298}$ See William H. Seward, The Assurance of Victory, Remarks at a Serenade in Rejoicing over the Reelection of President Lincoln (Nov. 10, 1864) ("The first year of the war suppressed the African slave trade in the United States."), in 5 SEWARD, supra note 270 , at 514 .

${ }^{299}$ Constitution OF the CONFederate States OF America art. 9 § 1.

300 See Sumner, supra note 158, at 485 (arguing that ratification would be seen by foreign nations as an "open pledge to Human Rights," while "the Rebels" would see it as "a new sign of the national purpose").

${ }^{301}$ See supra note 296. The favorable coverage of the treaty in the Northern press made little or no mention of the mixed courts and the constitutional issues they raised. Search, which had been actively contested for decades, was seen as the essence of the treaty. This was consistent with the focus of earlier discussions of the British program. See, e.g., A New Anti-Slave-Trade Treaty, N.Y. TIMES, Apr. 22, 1862, at 4 (noting that the treaty as passed by the Foreign Relations Committee had not been made public, preventing a debate on its merits).

${ }^{302}$ See, e.g., A NORTHERN MAN, supra note 297, at 29-37 ("Mr. Seward may think nothing of it, but this reversal of history, this renunciation of . . . ancient policy, gives a sharp pang."). The pamphlet focuses its ire on the concession of search. While the author also objects to the mixed commissions, see $i d$. at 31 , he treats them as a side issue because with the slave trade already over, they would not hear any cases-yet the right of search would still exist. See id. at 35-36 (characterizing the agreement as "a dark shadow that may yet harm America").

${ }^{303}$ One subsequent commentator wrote that "there was a general impression in the United States that it was quite doubtful whether such a tribunal could render an effective judgment" but did not explain how this impression was manifest. See Simeon E. Baldwin, The Proposed Trial of the Former Kaiser, 29 YALE L.J. 75, 77 (1919). 
later, Secretary of State Thomas Bayard, in official correspondence, dismissed the treaty as having been adopted in "peculiar circumstances" and not suggestive of general principles. ${ }^{304}$ If one discounts the original objections to the commissions as colored by anti-British sentiment, the subsequent abandonment of those objections should be at least equally discounted as being motivated by the opposite considerations.

\section{IMPLICATIONS FOR MODERN COURTS AND DEBATES}

This Part explores the significance of the slave-trade-court story for current constitutional questions. It first asks whether any lessons can be drawn from the rejection of the courts from 1818 to 1861, given the ultimate acceptance of slave-trade courts. Section V.A shows that the Civil War acceptance was not inconsistent with the positions taken by earlier administrations. At all times there was consensus that criminal tribunals would be unconstitutional. Section V.B discusses how various international tribunals would fare under the constitutional test that emerges in Section V.A and finds that many international courts would be acceptable. Section V.C finds that the ICC would run afoul of the principles consistently articulated by the U.S. government throughout the nineteenth century. It concludes by explaining how the ICC's nonreservation clause prevents the United States from joining with respect to those parts of the jurisdiction that would be constitutional. Section V.D. discusses an important modern argument in favor of the constitutional allocation of the ICC-that it should be regarded simply as a form of extradition and, thus, not constitutionally problematic. The slave-trade-court episode suggests three important differences between regular extradition and sending U.S. citizens to international courts for non-universal-jurisdiction offenses; this section explores the differences. Finally, Section V.E discusses what the slave-trade-court episode reveals about the possible resolution of two other major constitutional questions: whether there are any constitu-

${ }^{304}$ Letter from Thomas Bayard to Messrs. Sawyer \& Spooner (Apr. 19, 1886), in 2 JOHn BASSETT MOORE, A DigEST OF INTERNATIONAL LAW 948 (1906). Secretary Thomas Bayard, a former senator himself, was the son of the senator James Bayard who had originally opposed the treaty, and was a prominent "Peace Democrat" during the war. He opposed secession and is generally credited for keeping Delaware in the Union, but at the same time he challenged most aspects of Lincoln's response to the crisis. Thus, his narrow view of the treaty's significance is hardly surprising, and it highlights how much of the response to the treaty broke along the highly fraught political lines of the Civil War. 
tional limitations on the treaty power, and the extent to which Congress can domestically create non-Article III courts.

\section{A. Reconciling the Precedents}

The U.S. response to mixed courts for the slave trade consists of two contradictory precedents: the rejection of them as unconstitutional from 1818 to 1861 and a sudden reversal in 1861 that resulted in an entirely unused court from 1863 to 1870 . One might ask whether such confused history can add up to anything. This Section argues that the earlier rejectionist position seems to have quantitatively and qualitatively greater practice backing it. More importantly, the precedents are only partially contradictory: from Monroe's Administration through Lincoln's, it was agreed that participation in a tribunal that would have criminal jurisdiction over Americans would be unconstitutional. This undisputed proposition happens to be most relevant to the international courts that the United States might join in the near future.

\section{The Stronger Precedent}

Both in the 1820s and 1860s, positions on the treaty were largely congruent with the dominant political trends. In the 1820 s, when search was anathema and the British were still regarded with suspicion, the proposed British treaty was widely opposed, and it was easy for people to conclude that the mixed-commission proposal was unconstitutional. During the Civil War, by contrast, amity with the British was of paramount importance, and all who supported the war also supported the treaty.

Only in the 1820s did politicians of different views agree about the mixed commissions. ${ }^{305}$ The House of Representatives strongly favored a joint arrangement with the British, to the extent of endorsing the highly controversial concessions on search. Yet, while it expressed a willingness to adopt whatever measures were necessary to end the slave trade, it could not concede mixed commissions. These concessions against interest have no parallel in the Civil War episode, where the official view of the commissions lined up with expediency.

Furthermore, the earlier opposition to mixed courts was the product of greater deliberation. With the acceptance of the courts, the constitutional discussion was limited to one afternoon, with only

${ }^{305}$ A greater diversity of political views was represented in Congress in the $1820 \mathrm{~s}$ than in 1862, when many Southern seats were empty. 
one speech recorded. The treaty was an exceptional wartime measure. Its backers recognized this, as did subsequent historians. Finally, the acceptance of commissions only came after their role had become moot; back when the courts might have had an active docket, they were regarded as unconstitutional. In retrospect, the eventual acquiescence to Britain's longstanding proposal seems like a brief aberration, in a time of crisis, amidst an otherwise consistent practice.

Nonetheless, the fact that the reversal occurred almost by definition weakens the strength of the earlier precedent. It suggests, at the very least, that the Monroe Administration's constitutional views had not attained the kind of deep acceptance that would make such a treaty unthinkable. This might have been due in part to the nature of the precedent; inaction can only prove so much. But it also highlights the failure of the Monroe Administration to come up with a clear explanation of the constitutional objection. Of course, at the time, a briefworthy argument was not needed, for there was no appetite in Washington for signing the treaty in any case. When the political climate changed forty years later, however, the incompleteness of the Monroe Administration's constitutional arguments made it easier to pass the treaty.

\section{An Area of Agreement}

The ultimate acceptance of the treaty was reconcilable with the previous opposition. The Monroe Administration apparently saw the proposed tribunals as criminal courts. This distinguished them from prior international arbitral commissions, which only heard cases involving so-called public rights—civil claims against a sovereign. Senator Sumner emphasized their civil character in arguing for the opposite result in $1862 .{ }^{306}$

Everyone agreed that it would be unconstitutional to create international tribunals that would exercise criminal jurisdiction over U.S. citizens. A court that directly pronounced on the guilt of defendants would raise constitutional problems far beyond anything even the temporarily emboldened 1862 Senate could have accepted. The disagreement between Sumner and Adams concerned the acceptability of

${ }^{306}$ Determining which characterization is accurate is a hard question. Clearly the fact that the case would be in rem would not change its punitive and blame-assigning nature. The slave-trade commission was an unusual court of limited quasi-criminal jurisdiction. It was neither fish nor fowl and could be viewed as either criminal or civil depending on one's perspective or desired result. 
international courts to adjudicate cases that were less than criminal but more than pure "public rights," which all apparently agreed could be put before an international commission like the one created by the Jay Treaty. What they might have disagreed on are the intermediate situations-courts that would have jurisdiction over civil enforcement actions and common law claims involving private defendants. The implications of the slave-trade courts for criminal tribunals, however, are quite strong.

\section{B. Implications for International Courts}

The U.S. diplomacy regarding slave-trade courts demonstrates that there are serious constitutional questions about the use of international courts with direct jurisdiction over U.S. nationals. The precise limitations are somewhat less clear, and they depend on what one thinks the original objections to the courts were and the import of the courts' eventual acceptance during the Civil War. The U.S. reaction to the slave-trade courts supports one of two possible positions. The narrow view of the original rejection of the courts is that the criminal jurisdiction of the courts was essential to their constitutional infirmity. Yet the Constitution only treats criminal cases as a distinct category for certain purposes, such as jury trials and other procedural guarantees. Article III, however, does not generally treat criminal cases as a separate class. The objections to the mixed courts, by contrast, were broader. This broader view is that all such courts with civil or quasicriminal jurisdiction would also be unconstitutional; the permissibility of international courts tracks the public-rights/private-rights distinction rather than a criminal/civil distinction. The criminal jurisdiction limitation remains even if one takes the 1862 acceptance of the courts seriously. The 1862 acceptance does suggest, however, that international courts with powers over the property of American citizens could be constitutional.

Some implications for current international courts seem clear regardless of how one resolves the ambiguities. The North American Free Trade Agreement (NAFTA) tribunals decide public-rights casessuits challenging governmental regulatory policy. Because even the Monroe Administration did not see the rejection of the slave-trade courts as casting doubt on the Jay Treaty commission, it seems clear that tribunals that involve public rights, or that do not even involve private individuals, do not fall in the shadow of the slave-trade-court precedent.

The ICC, by contrast, raises precisely the same constitutional concerns that plagued the slave-trade commissions: the ICG is expressly 
criminal, for it directly punishes defendants. ${ }^{307}$ Thus, it would be precisely the kind of tribunal that was unanimously regarded as constitutionally suspect in the nineteenth century. ${ }^{308}$

However, the slave-trade-court experience does not rule out all participation in international criminal courts. Indeed, some of Adams's arguments suggest that some delegations to such tribunals could be constitutional. ${ }^{309}$ America might be able to subject its nationals to ad hoc criminal tribunals, like the modern "mixed commissions" used in Cambodia and Sierra Leone. The charter of such a court could limit its jurisdiction to avoid conflicts with the Constitution, for example, by only applying to extraterritorial acts by military personnel committed abroad or perhaps to universally cognizable offenses.

The implications for noncriminal international tribunals are the least clear. Some of the original objections to the slave-trade courts were based on an understanding that they were criminal in nature (which Article III makes particularly relevant). Moreover, the eventual adoption of the slave-trade treaty during the Civil War, with Sumner's caveat that it only exercise civil powers, suggests that international courts could be used for that branch of jurisdiction. Still, this conclusion seems somewhat less robust, given the extraordinary circumstances under which that treaty was adopted. Even for civil cases, the idea that the treaty power cannot trump individual rights is only relevant if the case is at "common law," in the language of the Seventh Amendment. ${ }^{310}$ It is unlikely that many cases heard by modern international tribunals could be described as "common law" matters, and thus the lack of jury should generally not be a problem in noncriminal cases. ${ }^{311}$

\section{The Rome Treaty's Overbreadth}

The slave-trade story does not rule out all participation in international criminal tribunals. Even if there are exceptions to their unconstitutionality for universal-jurisdiction crimes, military personnel,

307 See Rome Statute of the International Criminal Court, supra note 208, art. 77(1) (allowing the court to imprison defendants for up to thirty years for offenses within the jurisdiction of the court and up to life for certain serious crimes).

308 See supra subsection V.A.2.

${ }^{309}$ See supra subsections III.D.3-4.

310 See U.S. CONST. amend. VII (preserving the right to trial by jury for most suits at common law).

311 Similarly, the Seventh Amendment question would not have arisen under the Lyons-Seward Treaty because civil admiralty proceedings did not have juries. 
or acts in foreign territory, ${ }^{312}$ participation in the ICC would remain constitutionally dubious because its jurisdiction is not limited to those exceptions. $^{313}$ First, some of the offenses over which the ICC has jurisdiction, such as aggression and violations of the Geneva Convention short of grave breaches, are not universally cognizable. ${ }^{314}$ Other crimes that may be universally cognizable, like genocide, are defined in the Rome Statute far more broadly than their universal-jurisdiction status in customary international law. Lacking the participation of most great powers, who govern most of the people on Earth, ${ }^{315}$ the treaty does not establish a new rule of customary international law. ${ }^{316}$ No doubt the Rome Treaty represents an effort to develop international law. In the views of the Monroe Administration, at least, this would not be enough to allow foreign or mixed tribunals to judge U.S. citizens. During the debate over the slave-trade courts, international

312 See supra subsections III.D.3-5.

313 This also explains why the treaty's complementarity provisions may reduce but not eliminate the frequency of unconstitutional events. Complementarity allows the ICC to proceed with a case when the home state is "unwilling or unable genuinely to carry out the investigation or prosecution." Rome Statute of the International Criminal Court, supra note 208, art. 17(1). However, a jury acquittal, a decision by a U.S. Attorney not to bring charges, or a dismissal on a "technicality" particular to the United States could all be taken as "unwillingness" by the ICC. No U.S. Attorney has investigated former Secretaries of Defense Cohen and Rumsfeld for their alleged war crimes in Serbia and Iraq, respectively. This complete lack of prosecutorial interest could be taken as "unwillingness" sufficient to trigger the ICC's jurisdiction. The subsequent ICC prosecution would still suffer all the constitutional infirmities alleged by Adams. Under the treaty, the ICC has the last word in determining when complementarity applies, and this determination would not be reviewable by any U.S. court, which is precisely the problem that Adams stressed. See id. art. 17(2) (granting the ICC power to determine if a state's failure to prosecute is justified). Nothing in the slave-trade episode suggests that the mixed commissions would have been favored if they limited their activities to cases where the United States had chosen not to prosecute or had acquitted the defendant. Indeed, the opposite seems to be the case.

${ }^{314}$ See id. art. 8(2) (b) (cataloging "[o]ther serious violations of the laws and customs applicable in international armed conflict, within the framework of international law").

${ }^{315}$ The treaty has not been acceded to by the United States, China, India, Russia, or most Arab nations. See United Nations Treaty Collection, Status of Treaties, Rome Statute of the International Criminal Court, http://treaties.un.org/Pages/ Treaties.aspx?id=18\&subid=A\&lang=en (follow "Rome Statute of the International Criminal Court" hyperlink) (last visited Oct. 15, 2009).

316 Adams and Congress clearly took the position, supported by ample British and American case law, that treaties delegating jurisdiction did not create universal jurisdiction. See 42 ANNALS OF CONG. app. at 3029 (1823) (letter from John Quincy Adams to Alexander Everett) (writing that even after the United States and Britain declared the slave trade to be piracy, it was "essential" that vessels seized under the U.S.-British treaty were tried by their home state until "the consent of other nations to the general outlawry of this traffic as piracy”). This view still reflects international law. 
law on the slave trade was clearly evolving toward abolition. But the Monroe Administration believed that whatever exception might exist for universal crimes, the United States could not jump the gun by anticipating such developments. ${ }^{317}$

Similarly, the ICC's jurisdiction is in no way limited to military personnel. Normally, the United States avoids potential constitutional difficulties with treaty arrangements by attaching reservations that limit its treaty obligations to contexts where they would not violate the Constitution. However, the ICC treaty specifically bars such reservations, requiring signatory nations to agree to the entire package or none of it. ${ }^{318}$ Thus, if the United States joins the treaty, it would have to agree to apply it in the many foreseeable circumstances where it would be unconstitutional. Because of the "no reservations" clause, the applicability of the ICC to civilians and non-universal offenses would make Senate ratification of the treaty unconstitutional even if other applications might be constitutional.

Finally, the rejection of the mixed tribunals may have stemmed from their jurisdiction over U.S. territory. Yet the ICC exercises jurisdiction over the vessels and all the sovereign territory of all its members. ${ }^{319}$ Furthermore, the exercise of such authority is not speculative. Most war crime charges against the United States target senior officials for actions they committed in Washington, D.C. Moreover, the demise of strictly territorial notions of jurisdiction has also carried away the view that the Constitution's protections are strictly territorial. Even if Adams would have seen the unconstitutionality as limited, recent decisions about the applicability of the Constitution to foreigners abroad may make such a distinction hard to sustain. ${ }^{320}$

\section{The Extradition Analogy}

This Section considers two important arguments for the ICC in light of the slave-courts correspondence. Some scholars have argued that participating in the ICC would not raise any constitutional con-

${ }^{317}$ Interestingly, neither Adams nor members of Congress who reviewed his diplomatic correspondence thought that Congress's power to define and punish offenses against the law of nations gave that branch final say on what or when an offense had become universal in international law.

${ }^{318}$ See Rome Statute of the International Criminal Court, supra note 208, art. 120 ("No reservations may be made to this Statute.").

${ }^{319}$ See id. art. 12(2) (a).

${ }^{320}$ See, e.g., Boumediene v. Bush, 128 S. Ct. 2229, 2262 (2008) (granting the right of habeas corpus review to an alien detainee held in an area under United States control). 
cerns because it does not exercise the authority of the United States. A related claim is that participation in the ICC could be seen as no more problematic than an extradition treaty. This Section will explain how this latter argument was apparently rejected with regard to the slave courts and suggest some reasons why it may not have been persuasive.

U.S. citizens can, pursuant to extradition treaties, be sent for trial in foreign courts, although these courts do not provide defendants with American constitutional rights or judicial structures. ${ }^{321}$ Additionally, extradition does not raise Article III concerns: the foreign court is not exercising the judicial power of the United States, but rather its own authority. The only role the United States plays in an extradition is handing over the defendant. ${ }^{322}$

Similar arguments have been made in favor of participation in international courts, which are analogous to courts of a foreign state. ${ }^{323}$ The ICC has its own international legal personality and is independent of the United States. In this view, the lack of constitutional protections afforded by the ICC is as unimportant as the lack of such protections offered by any country to which Americans might be extradited.

Yet the mixed-commission precedent suggests that delegating judicial power to international courts in which the United States participates is more constitutionally problematic than extradition. The extradition argument could have been made with equivalent logic in defense of the slave-trade courts. Extradition mechanisms had existed since the Jay Treaty. ${ }^{324}$ The rendition of an alleged pirate to Britain in 1799 occasioned one of the sharpest and most memorable constitutional controversies of the early Republic. ${ }^{325}$ Yet no one defended mixed commissions as a type of extradition. While the constitutionality of extradition was largely untested in the 1820s, Sumner did not in-

${ }^{321}$ While the precise basis for the constitutionality of extradition is obscure, the practice has been decisively accepted in practice.

${ }^{322}$ See, e.g., Scheffer \& Cox, supra note 5, at 1015-19 (describing the practice of U.S. courts, when reviewing whether to extradite a defendant, of not inquiring into the due process protections or lack thereof in the receiving state).

${ }_{323}$ See, e.g., Daryl Mundis, Editorial Comment, The United States of America and International Justice: Has Lady Liberty Lost Her Way?, 2 J. INT'L CRIM. JUST. 2, 6 (2004) (arguing that there is no difference between extradition to a foreign country and to the ICC).

${ }^{324}$ See Jay Treaty, supra note 70, art. 27 (agreeing with Britain to mutually "deliver up to justice all persons, who, being charged with murder or forgery, committed within the jurisdiction of another, shall seek an asylum").

${ }^{325}$ See United States v. Robins, 27 F. Cas. 825, 833 (D.S.C. 1799) (No. 16,175) (upholding the extradition of an alleged mutineer of uncertain nationality to Britain pursuant to the 1794 Jay Treaty); Ruth Wedgwood, The Revolutionary Martyrdom of Jonathan Robbins, 100 YALE L.J. 229 (1990) (discussing the Robins case and its implications). 
voke extradition as a precedent in 1862, even though by then the first cases broadly sustaining its constitutionality had been decided. ${ }^{326}$

One can try to understand why the nineteenth-century view did not see the slave-trade tribunals as purely foreign courts outside the application of the Constitution. International courts and foreign states can be distinguished by the source of their jurisdiction. Extradition has always been understood as the rendition of someone to a foreign state within whose sovereign jurisdiction she had allegedly committed a crime. ${ }^{327}$ The constitutional justification is that otherwise the United States, unable to punish the offenders, would become a haven for criminals. ${ }^{328}$ Extradition merely gives the foreign state personal jurisdiction; it does not create subject-matter or prescriptive jurisdiction. Yet with the mixed commissions, as with the ICC, it is the "extradition" treaty itself that gives the non-U.S. tribunal authority over U.S. nationals or territory. ${ }^{329}$

In extradition cases, the foreign state is exercising its own sovereign authority. With mixed courts, on the other hand, the authority would have been delegated by the United States. This may help explain one of the Monroe Administration's recurring objections to the

${ }^{326}$ See, e.g., In re Kaine, 55 U.S. (14 How.) 103, 112-13 (1852) (plurality opinion) (noting with approval the practice of extradition).

${ }^{327}$ The Jay Treaty, as well as subsequent extradition agreements, have been confined to crimes "committed within the jurisdiction" of the parties. See, e.g., Jay Treaty, supra note 70, art. 27. Indeed, James Madison explained that

[t] his [extradition] act authorises [ye] surrender of a Citizen to a foreign Sovereign within whose acknowledged jurisdiction the citizen shall commit a crime, of [which] satisfactory proof shall be exhibited to Congress, and for which in the judgment of Congress the law of nations exacts such surrender.... The opponents contended that such surrenders were unknown to the law of nations, and were interdicted by our declaration of Rights.... With regard to the bill of rights, it was alleged to be no more or rather less violated by considering crimes committed [against] other laws as not falling under the notice of our own, and sending our Citizens to be tried where the cause of trial arose, than to try them under our own laws without a jury of the vicinage, and without being confronted with their accusers or witnesses; as must be the case, if they be tried at all for such offences under our own laws.

Letter from James Madison to Thomas Jefferson (Jan. 9, 1785), in 2 THE WRITINGS OF JAMES MADISON 110-11 (Gaillard Hunt ed., 1901) (emphasis added).

${ }^{328}$ See Letter from James Madison to Thomas Jefferson, supra note 327, at 111 ("And to say that such offenders [against foreign law] could neither be given up for punishment, nor be punished within their own Country, would amount to a licence for every aggression...." (emphasis added)).

${ }^{329}$ The ICC might obtain jurisdiction over Americans based on their presence in the territory of another member State, but the discussion here focuses on that jurisdiction which is a result of U.S. participation in the treaty. 
tribunals. Wirt thought the slave-trade court, unlike the Jay Treaty commission, was unconstitutional because it would "carry into effect our municipal and penal statutes." "330 The conduct that the mixed commissions would punish was criminal under U.S. law. The commission would only have jurisdiction if given it by treaty, and it was the constitutionality of such a treaty that was itself in question.

There is no constitutional precedent to support the extradition for trial in Saudi Arabia of a U.S. citizen for a pickpocketing that happened in New York. That is judicial outsourcing, not extradition. It goes beyond the rationale for allowing extradition in the first place. Indeed, the extradition analogy may have been anticipated by Adams when he told Canning that trial before a purely foreign tribunal would be unconstitutional. $^{331}$ There was no constitutional problem per se with sending an American for trial before a British court. But that presumed the crime was committed within British jurisdiction. Because the slave trade was not yet piracy under international law, it was an offense only against the jurisdiction of the United States. Sending offenders for trial in Britain would in effect have been extradition to a random country. ${ }^{332}$

Moreover, the involvement of U.S. judges makes international tribunals entirely different from a typical extradition. It makes it in part an exercise of U.S. power. ${ }^{333}$ Paradoxically, rendering a U.S. national to

${ }^{330}$ Diary Entry of John Quincy Adams, supra note 104, at 151; see also United States v. Watkins, 28 F. Cas. 419, 462 (C.C.D.C. 1829) (No. 16,649) (Thruston, J., dissenting) ("The negotiation with Great Britain, respecting the suppression of the slave trade, failed upon the ground that the United States could not give power to the courts of another nation to punish the violation of the laws of the United States."); Letter from Albert Gallatin to John Quincy Adams, supra note 200, at 229-30 (arguing that it would violate the Constitution for mixed commissions to try citizens for "violation of our own laws").

${ }^{331}$ Canning had sarcastically suggested to Adams that if mixed courts were constitutionally problematic, there could be no problem with prosecuting slave traders in "the ordinary way": by regular (British) admiralty courts. See 42 ANNALS OF CONG. app. at 3007-08 (1823). Not surprisingly, Adams rejected this uneven proposal out-of-hand:

[I]t might seem needless to remark, that the Constitutional objection could not diminish in proportion as its cause should increase, or that the Power incompetent to make American citizens amenable to a court consisting one-half of foreigners, should be adequate to place their liberty, their fortune, and their fame, at the disposal of tribunals, entirely foreign.

42 ANNALS OF CONG. app. at 3010, 3012 (1823).

${ }^{332}$ See id. at 3012 (arguing that under the Constitution there is no right for another nation to try local offenders).

${ }^{333}$ It is difficult to say what proportion of American judges makes a tribunal "mixed" enough to be considered an exercise of the judicial power of the United States. The slave-trade precedent suggests that as little as one-third is a problem, and 
an international tribunal on which the United States is not represented may be constitutionally less problematic than giving her over to a mixed court, though of course it would be more difficult politically.

One might answer the extradition analogy by observing that, to the extent the international court has jurisdiction over U.S. citizens, it is because it has been given those powers by the United States. That action is in functional terms a delegation of U.S. authority. The ICC certainly cannot violate Article III or any other constitutional provision. Yet the signing and ratification of a treaty empowering it is surely an exercise of the legislative and executive power of the United States. The response to the slave-trade court shows that even if constitutional arguments do not lie against the court, they can be made directly against the treaty that empowers it.

Professor Pfander makes a more nuanced version of the "nonU.S." argument. In his view, the legitimacy of non-Article III courts is based on the Tribunals Clause of Article I, which gives Congress considerable latitude to create tribunals so long as they remain in some sense inferior to Article III tribunals. International courts, however, are not "constituted" by Congress. ${ }^{334}$ Thus, the Tribunals Clause is inapplicable, and there is no need for such courts to be amenable to Article III judicial review. ${ }^{335}$ This conclusion follows nicely from Professor Pfander's basic view of the inferiority requirement. It is also potentially consistent with the slave-trade precedent. In a two-nation mixed tribunal, without the participation of one country, there is no international court. As the number of participating nations increases, the argument that the additional ones "constitute" an already existing court decreases. (The Monroe Administration did repeatedly use words like "establish" and "institute" to describe the role that the United States

the ICC sits in panels of three (though U.S. participation in a U.S. case is not guaranteed). Still, were an American to sit on a three-judge panel, she would be left with the outcome-determinative decision whenever the other two were divided. It would be hard to say in such a case that the U.S. involvement was diluted to the extent of being inconsequential. Still, with a large enough panel of judges, one can imagine the U.S. role being de minimis.

334 See Pfander, supra note 25, at 767-68 (highlighting how NAFTA panels are not standard Article III tribunals). Put differently, this view would say that while nonArticle III courts created under the Tribunals Clause must be inferior, the Treaty Clause contains no such requirement for tribunals that might be created or joined through that power.

See id. Pfander notes that while such courts may not be objectionable on nondelegation grounds, they would still have to adhere to other constitutional norms. See $i d$. at 768 n.596 (describing constitutional protections in extradition hearings). 
was being asked to play in relation to the mixed courts, though this again may have been a function of their binational structure.)

Yet the response to the extradition argument may be repeated here, though perhaps not as forcefully. While international courts are not "creatures of Congress," Americans, it is because they have been given these powers by American officials. While an international court as a whole may not be "constituted" by Congress, its applicability to Americans in a sense is. By ratifying the Rome Statute, one might think that the Senate "constitutes" the ICC as a court that can try Americans, even though the ICC was already constituted with respect to other countries.

\section{E. Non-Article III Courts and the Treaty Power}

To say-as Missouri $v$. Holland did-that the treaty power is unencumbered by vertical restraints of federalism is one thing; to say that horizontal checks do not matter is a much broader extension. The former means federalism does not apply when the United States acts internationally. This makes sense-federalism is an internal arrangement, but the country must present a unified face to the world. The latter, broader position would mean that Congress could, pursuant to a treaty, gut the powers of the other branches. Adams's view that Congress can create international courts as long as there would be some Article III review treats the international courts as something like territorial courts. In international matters one need not worry about Article III's role in protecting the jurisdiction of the courts of quasi-sovereign states, yet checks and balances on the level of the national government still apply.

The understanding of the treaty power articulated at the time suggests that it is limited by more than just Bill of Rights protections. It is also limited at least by structural provisions designed for individual benefit, such as the review of convictions by an Article III tribunal. As for the question of permissibility of non-Article III courts, the understanding adopted appears to track something like the public/private rights distinction, perhaps giving some greater credibility to this much maligned distinction. 


\section{CONCLUSION}

The constitutionality of the International Criminal Court is not a case of first impression. The slave-trade courts proposed by Britain provide the closest analogy available to the ICC-they were specifically designed to deal with criminal human rights offenses committed by U.S. citizens. Despite the conflicted nature of the slave-trade-court precedent, one proposition was agreed to by everyone from 1818 to 1870: for criminal matters involving U.S. citizens, jurisdiction can only be given to international tribunals that are reviewable by Article III courts and that provide jury trials and related constitutional rights protections.

The history is too specific to categorically reject the constitutionality of international criminal courts. If anything, it confirms that using international tribunals more generally does not necessarily create nondelegation problems. Instead, it suggests limits on the jurisdiction and procedures of courts in which the United States could participate. Thus, the history can be seen as providing a basis for designing international courts that avoid constitutional obstacles. For example, universally cognizable crimes and offenses by service members may be exceptions to the rule against American participation in international criminal tribunals. This would allow for the United States to agree to much of that with which international criminal tribunals currently concern themselves.

The story of the slave-trade courts also offers some more general lessons. First, it demonstrates that American exceptionalism in international law-the rejection of participation in certain large international legal institutions-did not begin in recent years. This is at least a partial correction to the argument that the United States enthusiastically supported international institutions in the Republic's early years, when its power was weak. ${ }^{337}$

Second, the British plan combined both executive and judicial functions: a dedicated naval squadron with the mixed courts. The former was much more expensive to maintain than the latter. Yet the judicial phase could only be successful to the extent that the navy was searching suspect ships. The pursuit of a search treaty by Britain and its signature by Adams even after mixed courts had been rejected sug-

337 See Robert Kagan, Of PARAdise ANd POWER: America ANd Europe in the NEW WORLD ORDER 9 (2003) (arguing that American foreign policy in the early years of the Republic was more concerned with advancing international law, which the fledgling state hoped would constrain greater powers more than itself). 
gests that everyone agreed that if one had to choose between the executive and judicial components, the former would be more important. By contrast, today's international criminal courts invariably divorce enforcement from adjudication, focusing solely on the latter. As a result, they have great difficulty bringing cases, especially since the crimes in their purview are generally committed by organized armed forces often backed by a government. 